\title{
Dung beetles of Brazilian pastures and key to genera identification (Coleoptera: Scarabaeidae)
}

\author{
Ana Silvia de Oliveira Tissiani ${ }^{(1)}$, Fernando Zagury Vaz-de-Mello ${ }^{(1)}$ and José Holanda Campelo-Júnior ${ }^{(1)}$
} (1)Universidade Federal de Mato Grosso, Avenida Fernando Corrêa da Costa, oㅡ2.367, Boa Esperança, CEP 78060-900 Cuiabá, MT, Brasil.
E-mail: atissiani@gmail.com, vazdemello@gmail.com, campelo@cpd.ufmt.br

\begin{abstract}
The objective of this work was to elaborate supporting tools for the correct identification of Scarabaeidae, by an identification key of genera, and a commented list of the species present in Brazilian pastures. A data survey was performed on the specimens deposited in the main Brazilian collection and reported on the recent scientific literature. The distribution of the species was identified in the Brazilian states, based on information on feeding preference, ecological aspects, and potential for faeces removal action. The species were classified according to their importance for pastures, as: high, medium, and low. A key for the identification of the genera and subgenera of Scarabeidae present in the pastures was constructed through the analysis of the external morphology of the species and, when needed, by the analysis of sexual traits. Twenty genera and 76 species of scarab beetles were recorded for Brazilian pasturelands, among which Dichotomius bos, Dichotomius nisus, Trichillum externepunctatum, Ontherus appendiculatus, Onthophagus aff. hirculus, and Digitonthophagus sp. were considered as the most frequent, widely distributed, abundant, and important. The dichotomous key will contribute to the identification of the genera and subgenera of dung beetles (Scarabaeidae: Scarabaeinae) occurring in the Brazilian pastures.
\end{abstract}

Index terms: biological control, coprophagous beetles, dichotomous key, Scarabaeinae, taxonomy.

\section{Besouros rola-bostas das pastagens brasileiras e chave para identificação dos gêneros (Coleoptera: Scarabaeidae)}

\begin{abstract}
Resumo - O objetivo deste trabalho foi elaborar ferramentas de apoio para a correta identificação de Scarabaeidae, por meio de uma chave para identificação de gêneros, e a lista comentada das espécies presentes nas pastagens brasileiras. Levantaram-se os espécimes depositados na principal coleção brasileira e relatados na literatura científica recente. Identificou-se a distribuição das espécies nos estados brasileiros, com informações sobre a preferência alimentar, os aspectos ecológicos e os potenciais para a ação de remoção de fezes. As espécies foram classificadas, de acordo com o grau de importância para pastagens, em: alta, média e baixa. Por meio da análise da morfologia externa das espécies e, quando necessário, dos caracteres sexuais, construiu-se uma chave para a identificação dos gêneros e dos subgêneros de escarabeídeos presentes nas pastagens. Registraram-se 20 gêneros e 76 espécies de besouros rola-bostas para as pastagens brasileiras, entre as quais Dichotomius bos, Dichotomius nisus, Trichillum externepunctatum, Ontherus appendiculatus, Onthophagus aff. hirculus e Digitonthophagus sp. foram consideradas as mais frequentes, amplamente distribuídas, abundantes e importantes. A chave dicotômica contribuirá para a identificação dos gêneros e dos subgêneros de rola-bostas (Scarabaeidae: Scarabaeinae) que ocorrem nas pastagens brasileiras.
\end{abstract}

Termos para indexação: controle biológico, besouros coprófagos, chave dicotômica, escarabeíneos, taxonomia.

\section{Introduction}

Deposition of manure across pastures and the occurrence of parasitic Diptera are among the main ecological problems caused by the introduction of cattle in several regions of the planet. These problems are most intense where there have been losses of herbivorous mammals from the native megafauna, such as those occurring in South America and Australia
(Waterhouse, 1974; Halffter, 1991; Nichols et al., 2008; Vieira et al., 2008).

This deposition of manure, which can accumulate on the pastures' grasses, causes the reduction of green matter available for feeding the animals. Part of the leaves are unable to survive the shade, and some become unpalatable to the cattle (Waterhouse, 1974).

Another problem caused by the deposition of fecal matter in pastures is the proliferation of parasitic 
insects and worms that use bovine manure as a substrate to complete their life cycle (Waterhouse, 1974; Flechtmann et al., 1995a; Nichols et al., 2008; Vieira et al., 2008). The fecal matter deposited in pastures is also used by scarab beetles (Coleoptera: Scarabaeidae), which are commonly called dung beetles, as they dismantle the fecal matter, mold portions of the feces into a spherical shape, and transport it to burrows excavated in the soil (Halffter $\&$ Matthews, 1966). While burying portions of feces, the dung beetles bury other insects and fecal worms together, which are harmful to the herds (Flechtmann et al., 1995a; Louzada \& Silva, 2009; Ridsdill-Smith \& Edwards, 2011).

Elaborate nesting, associated with the broad geographical distribution and high biomass of many of its species, and the greater number of coprophagous species than other Coleoptera families, make scarab bettles the most important Brazilian coprophagous beetles (Louzada \& Silva, 2009).

In Brazil, concern about the advance of the horn fly (Haematobia irritans Linnaeus, 1758) caused Embrapa to introduce, at the end of the $1980 \mathrm{~s}$, the Afro-Asian beetle Digitonthophagus gazelle (Fabricius 1787), an important agent in the control of $H$. irritans (Bianchin et al., 1998; Matavelli \& Louzada, 2008). This introduction followed the model previously adopted in other parts of the world (Noriega et al., 2010). At the time, there were no studies on the native fauna of coprophagous beetles of Brazilian rural environments, which corroborated the decision to introduce this exotic species (Vaz-de-Mello, 2000). Existence of wellstructured native communities of dung beetles, which efficiently perform the service of the dismantling and removal of fecal matter, is now recognized in all biomes of the country (Louzada \& Silva, 2009).

The number of species present in pastures is regionally affected by the composition of the original vegetation, the time the pastures take to form, their isolation, grass composition, stability and environmental complexity (Almeida et al., 2011). The species of dung beetles present in rural vegetation are numerically and qualitatively different between native and cultivated grasslands (Almeida et al., 2011). Few species are present in all Brazilian biomes, which is indicative that they should be the focus of research in biological control and other services provided by dung beetles in pastures. However, a number of species occur in virtually all types of rural compositions in the country and, therefore, are considered to be of high importance to these environments. Considering, at least, 100 years of inventory of the Scarabaeidae species in the country and the proven efficacy of the inclusion of dung beetles as important biological agents in agropastoral systems, this study became necessary.

The objective of this work was to elaborate supporting tools for the correct identification of Scarabaeidae, by an identification of key genera, and a commented list of the species present in Brazilian pastures.

\section{Materials and Methods}

Specimens of coprophagous Scarabaeidae, deposited in the sector of entomology of the zoological collection of Universidade Federal de Mato Grosso, were examined between January 2012 and November 2015. This collection is a reference for Scarabaeidae in Brazil and has duplicates of published specimens (Vieira et al., 2008; Almeida \& Louzada, 2009; Costa et al., 2009; Louzada \& Silva, 2009). Currently, it is considered quantitatively and qualitatively the largest and most important collection of dung beetles in the country, with specimens from all regions of Brazil and across the globe, making it possible to assemble a list of Brazilian species.

In addition, a literary review of articles published up to November 2015 was carried out in scientific journals (Table 1). From the list of species, it was possible to identify their distribution in the Brazilian states, and information on food preference, ecological aspects, and potential for fecal removal action was added according to classification criteria described by Halffter \& Matthews (1966).

Species were classified into high, medium and low importance for pastures. The dung beetles considered highly important, were those most functionally important in Brazilian pastures due to their burial habits and species size. Species with restricted distribution, but with high regional importance, were classified as of medium importance, because they were found with a high number of individuals or with a high body mass. The species of low importance are present in local distribution or low abundance, often with little or totally unknown biology, or with diverse eating and 
ecological habits, but that eventually frequent the feces in pastures.

From Vaz-de-Mello et al. (2011) and based on the analysis of the external morphology of the species, including - where necessary - the sexual characters, a key was constructed to identify the genera and subgenera of scarab beetles present in Brazilian pastures.

\section{Results and Discussion}

Brazilian dung beetle fauna is composed of 716 species and 61 subspecies described so far, belonging to 63 genera (Vaz-de-Mello, 2015). Most of them are associated with forest formations. In the almost $23 \%$ of Brazilian territory covered by pastures, only 20 genera and 76 species of dung beetles were recorded,

Table 1. Geographic localization, sampling method and information sources of Brazilian coprophagous Scarabaeidae in pastures, used to obtain the distribution of these species in the Brazilian territory.

\begin{tabular}{|c|c|c|c|}
\hline Municipality, State, and geographic localization & Sampling method & Sample effort & Source \\
\hline Aquidauana, MS & Pitfall traps baited with cattle dung & 48 weeks & Aidar et al. (2000) \\
\hline Carrancas, $\mathrm{MG}\left(\sim 21^{\circ} 35^{\prime} \mathrm{S}, 44^{\circ} 34^{\prime} \mathrm{W}\right)$ & $\begin{array}{l}\text { Pitfall traps baited with human dung } \\
\text { or bovine spleen }\end{array}$ & 48 hours & Almeida \&Louzada (2009) \\
\hline $\begin{array}{l}\text { Charles Darwin Ecological Refuge, Igarassu, PE } \\
\left(7^{\circ} 48^{\prime} 37^{\prime \prime} \mathrm{S}, 34^{\circ} 27^{\prime} 25^{\prime \prime} \mathrm{W}\right)\end{array}$ & Flight-intercept traps & 3 weeks & Costa et al. (2009) \\
\hline Jaraguá do Sul, SC $\left(26^{\circ} 29^{\prime} \mathrm{S}, 49^{\circ} 04^{\prime} \mathrm{W}\right)$ & Manual collection in cattle fecal pads & 6 days & Flechtmann \& Rodrigues (1995) \\
\hline Selvíria, MS $\left(20^{\circ} 24^{\prime} \mathrm{S}, 51^{\circ} 19^{\prime} \mathrm{W}\right)$ & $\begin{array}{l}\text { Manual collection in cattle fecal pads } \\
\text { and light-trap }\end{array}$ & 1 year & Flechtmann et al. (1995b, 1995c, 1995d) \\
\hline Ilha Solteira, SP $\left(20^{\circ} 22^{\prime} \mathrm{S}, 51^{\circ} 22^{\prime} \mathrm{W}\right)$ & Manual collection in cattle fecal pads & 4 months & Flechtmann et al. (1995a) \\
\hline $\begin{array}{l}\text { Farm of Embrapa Beef Cattle, Campo Grande, MS } \\
\left(\sim 20^{\circ} 27^{\prime} \mathrm{S}, 54^{\circ} 37^{\prime} \mathrm{W}\right)\end{array}$ & Collection in cattle fecal pads & 2 years & Koller et al. (1999) \\
\hline $\begin{array}{l}\text { Farm of Embrapa Beef Cattle, Campo Grande, MS } \\
\left(\sim 20^{\circ} 27^{\prime} \mathrm{S}, 54^{\circ} 37^{\prime} \mathrm{W}\right)\end{array}$ & Pitfall traps baited with cattle dung & 3 years & Koller et al. (2007) \\
\hline Londrina, PR $\left(23^{\circ} 27^{\prime} \mathrm{S}, 51^{\circ} 15^{\prime \prime} \mathrm{W}\right)$ & Pitfall traps baited with dung & 1 year & Lopes et al. (2011) \\
\hline Viçosa, $\mathrm{MG}\left(20^{\circ} 45^{\prime} \mathrm{S}, 42^{\circ} 50^{\prime} \mathrm{W}\right)$ & Bovine or horse manure & 48 hour & Louzada \& Silva (2009) \\
\hline Vilela Farm, Itumbiara, $\mathrm{GO}\left(18^{\circ} 25^{\prime} \mathrm{S}, 49^{\circ} 13^{\prime} \mathrm{W}\right)$ & $\begin{array}{l}\text { Manual collection in bovine fecal } \\
\text { pads }\end{array}$ & 1 year & Marchiori (2000) \\
\hline Vilela Farm, Itumbiara, $\mathrm{GO}\left(18^{\circ} 25^{\prime} \mathrm{S}, 49^{\circ} 13^{\prime} \mathrm{W}\right)$ & Berlese funnel with bovine manure & 1 year & Marchiori et al. (2001) \\
\hline Vilela Farm, Itumbiara, $\mathrm{GO}\left(18^{\circ} 25^{\prime} \mathrm{S}, 49^{\circ} 13^{\prime} \mathrm{W}\right)$ & $\begin{array}{l}\text { Manual collection in bovine fecal } \\
\text { pads }\end{array}$ & 10 months & Marchiori et al. (2003) \\
\hline Canchim Farm, São Carlos, SP $\left(21^{\circ} 1^{\prime} \mathrm{S}, 47^{\circ} 53^{\prime} \mathrm{W}\right)$ & $\begin{array}{l}\text { Berlese funnel and manual collection } \\
\text { in bovine fecal pads }\end{array}$ & 1 year & Mendes \& Linhares (2006) \\
\hline Canchim Farm, São Carlos, SP (2201'S, 4753'W) & Pitfall traps baited with cattle dung & 3 months & Oliveira et al. (1996) \\
\hline São Luís Island, MA $\left(2^{\circ} 36^{\prime} \mathrm{S}, 44^{\circ} 16^{\prime} \mathrm{W}\right)$ & Pitfall traps baited with cattle dung & 3 months & Pereira et al. (2003) \\
\hline Selvíria, MS $\left(20^{\circ} 24^{\prime} \mathrm{S}, 51^{\circ} 19^{\prime} \mathrm{W}\right)$ & Manual collection in cattle fecal pads & 1 month & Rodrigues \& Flechtmann (1997) \\
\hline Piracicaba, SP $\left(22^{\circ} 42^{\prime} \mathrm{S}, 47^{\circ} 37^{\prime} \mathrm{W}\right)$ & Pitfall traps baited with cattle dung & 10 months & Rodrigues \& Marchini (1998) \\
\hline Nhumirim Farm, Corumbá, MS $\left(18^{\circ} 59^{\prime} \mathrm{S}, 56^{\circ} 39^{\prime} \mathrm{W}\right)$ & Light-trap & 13 months & Rodrigues et al. (2010) \\
\hline Tamarana, $\mathrm{PR}\left(25^{\circ} 27^{\prime} \mathrm{S}, 51^{\circ} 15^{\prime} \mathrm{W}\right)$ & Light-trap & 13 months & Ronqui \& Lopes (2006) \\
\hline Marajoara Farm, Pau d'Arco, PA $\left(7^{\circ} 50^{\prime} \mathrm{S}, 50^{\circ} 16^{\prime} \mathrm{W}\right)$ & Pitfall traps baited with dung & 1 month & Scheffler (2005) \\
\hline Linhares, ES $\left(19^{\circ} 15^{\prime} 16^{\prime \prime S}, 39^{\circ} 47^{\prime} 28^{\prime \prime} \mathrm{W}\right)$ & $\begin{array}{l}\text { Pitfall traps baited with human dung } \\
\text { or spleen or banana }\end{array}$ & 4 months & Schiffler et al. (2003) \\
\hline Caruaru, $\mathrm{PE}\left(20^{\circ} 27^{\prime} \mathrm{S}, 54^{\circ} 37^{\prime} \mathrm{W}\right)$ & Pitfall traps baited with human dung & 10 months & Silva et al. (2007) \\
\hline Bagé, RS (31¹6'49"S, 5359'2"W) & $\begin{array}{l}\text { Pitfall traps baited with bovine dung } \\
\text { or decayed bovine liver }\end{array}$ & 15 days & Silva et al. (2008) \\
\hline Bagé, RS ( $\left.31^{\circ} 21^{\prime} \mathrm{S}, 54^{\circ} 00^{\prime} \mathrm{W}\right)$ & $\begin{array}{c}\text { Pitfall traps baited with human dung, } \\
\text { banana or liver and flight-intercept } \\
\text { traps }\end{array}$ & 1 year & Silva et al. (2012) \\
\hline $\begin{array}{l}\text { Charles Darwin Ecological Refuge, Igarassu, PE } \\
\left(7^{\circ} 48^{\prime} 37^{\prime \prime}, 34^{\circ} 27^{\prime} 25^{\prime \prime}\right)\end{array}$ & $\begin{array}{l}\text { Pitfall traps baited with human dung } \\
\text { or carcass }\end{array}$ & 1 year & Silva et al. (2010) \\
\hline $\begin{array}{l}\text { Guajará Mirim and Nova Mamoré, } \mathrm{RO}\left(\sim 10^{\circ} 40^{`} \mathrm{~S} \text {, }\right. \\
\left.64^{\circ} 50^{\prime} \mathrm{W}\right)\end{array}$ & $\begin{array}{l}\text { Pitfall traps baited with human or } \\
\text { bovine dung orbovine spleen }\end{array}$ & 48 hours & Silva et al. (2014) \\
\hline Guriri Island, São Mateus, ES $\left(18^{\circ} 45^{\prime} \mathrm{S}, 39^{\circ} 44^{\prime} \mathrm{W}\right)$ & $\begin{array}{l}\text { Pitfall traps baited with horse or } \\
\text { human dung }\end{array}$ & 3 months & Vieira et al. (2008) \\
\hline
\end{tabular}


of which Dichotomius bos (Blanchard, in Blanchard \& Brullé, 1845), Dichotomius nisus (Olivier, 1789), Trichillum externepunctatum Preudhomme de Borre, 1880, Ontherus appendiculatus (Mannerheim, 1829), Onthophagus aff. hirculus, and Digitonthophagus sp. were considered to be of high importance for these environments, since they present a wide distribution and greater body biomass and, potentially, remove the greatest amount of manure to the interior of the soil. Six species were considered of medium importance (Table 2), and 64 species of low importance (Table 3).

The following list of dung beetle genera present in Brazilian pastures were highlighted from the evaluated data, with comments detailing the main species within this environment:

Agamopus Bates, 1887 - this genus has four described species, two of which from Brazilian pastures (Halffter \& Martínez, 1968), and has at least one new species. Which species that occur in pastures are copronecrophagous and appear to exhibit oviposition behavior in other Scarabaeidae nests of the genera Dichotomius, Isocopris, and Ontherus (Vazde-Mello, 2007) (Table 3, Figure 1).

Ateuchus Weber, 1801 - a highly specious genus, and in urgent need of taxonomic revision, with over than 80 described species, of varied forms, habits and habitats. They often occur with a high number of individuals (Table 3 ).
Canthidium Erichson, 1847 - a genus with more than 150 species, and an urgent need for taxonomic revision. It presents species of medium and low importance for pastures, among them Canthidium decoratum Perty, 1830, considered an indicator of Cerrado and Canthidium marseuli Harold, 1867, an indicator of native pastures (Almeida \&Louzada, 2009) (Tables 2 and 3; Figure 2).

Canthon Hoffmannsegg, 1817 - a genus with over 160 species currently valid, 13 of which were recorded in Brazilian pastures. From species that are widely distributed across pastures all over the country, such as the Canthon mutabilis Lucas, 1857, to species present exclusively in high altitude fields (above $800 \mathrm{~m}$ ), in Cerrado and Atlantic Forest transition areas, like the Canthon corpulentus Harold, 1868, erroneously cited as Canthon lamproderes Redtenbacher, 1867 according to Vaz-de-Mello et al. (2013). The species Canthon cyanescens Harold, 1868 - erroneously referred to in literature as Canthon latipes (Blanchard, in Blanchard \& Brullé, 1845) - and Canthon nigripennis Lansberge, 1874 were eventually observed in pastures near forests and clearings (Table 3; Figure 1).

Chalcocopris Burmeister, 1846 - to date, this genus has two species, Chalcocopris hesperus (Olivier, 1789) and Chalcocopris inexpectatus (Rossini \& Vazde-Mello, 2015). Only C. hesperus, a coprophagous species with diurnal habits, was seldom found in

Table 2. Dung beetle species (Coleoptera: Scarabaeidae: Scarabaeinae) classified as of medium importance for Brazilian pastures.

\begin{tabular}{|c|c|}
\hline Species & Additional information \\
\hline Dichotomius aff. quadraticeps Felsche, 1901 & $\begin{array}{l}\text { Found in pastures and natural fields up to about } 1,000 \mathrm{~m} \text { altitude, in matrix of Cerrado } \\
\text { (Almeida \& Louzada, 2009). Was identified as Dichotomius ascanius Harold, } 1869 \text { in } \\
\text { almost all publications (Koller et al., 2007; Almeida \&Louzada, 2009). }\end{array}$ \\
\hline Dichotomius semisquamosus (Curtis, 1845) & $\begin{array}{l}\text { Widely reported from sea level up to } 1,000 \mathrm{~m} \text { altitude - in degrade environments, } \\
\text { clearings and pastures -, Atlantic forest, Restinga, and Caatinga, between Southeast (in } \\
\text { the states of Rio de Janeiro, Minas Gerais, and Espirito Santo) and Northeast regions. }\end{array}$ \\
\hline Ontherus sulcator Fabricius, 1775 & $\begin{array}{l}\text { Considered with unusual geographic distribution, spread in areas of the Eastern Amazon } \\
\text { Forest, throughout Chaco Depression (including Pantanal and Pampas), and South, in } \\
\text { Atlantic Forest areas (Morrone, 2001). }\end{array}$ \\
\hline Canthidium barbacenicum Preudhomme de Borre, 1886 & $\begin{array}{l}\text { In Cerrado and Chaco areas are commonly distributed in pastures and degraded } \\
\text { environments, even countries bordering Brazil. Cited as Canthidium megathopoides } \\
\text { Boucomont, } 1928 \text { in Rodrigues \& Flechtmann (1997). }\end{array}$ \\
\hline Onthophagus buculus Mannerheim, 1829 and close species & $\begin{array}{c}\text { Similar to } O \text {. hirculus, originally described in the municipality of Diamantina, in the } \\
\text { state of Minas Gerais, region, and associated with pastures and natural fields of Cerrado. } \\
\text { Several species under this name require urgent revision. }\end{array}$ \\
\hline Onthophagus ranunculus Arrow, 1913 and close species & $\begin{array}{l}\text { Described as originating in municipality of Natal, in the state of Rio Grande do Norte; } \\
\text { close associated to Caatinga and coastal savannas of the Northeast. At least one closely } \\
\text { specie occurs in central part of Brazilian Cerrado. This close specie is mistakenly } \\
\text { identified as Onthophagus rubrescens Blanchard, 1846, in Louzada \& Silva (2009). }\end{array}$ \\
\hline
\end{tabular}

Pesq. agropec. bras., Brasília, v.52, n.6, p.401-418, jun. 2017 
Table 3. Dung beetle species (Coleoptera: Scarabaeidae: Scarabaeinae) classified as low importance that occur in Brazilian pastures.

\begin{tabular}{|c|c|c|c|c|c|c|c|c|c|c|}
\hline \multirow{2}{*}{$\begin{array}{l}\text { Species } \\
\text { Agamopus unguicularis (Harold, 1883) }\end{array}$} & \multicolumn{10}{|c|}{ States ${ }^{(5)}$ with confirmed distribution } \\
\hline & MG & SP & $\mathrm{PR}$ & $\mathrm{SC}$ & & & & & & \\
\hline Agamopus viridis Boucomont, 1928 & BA & ES & GO & MG & MS & MT & RJ & SP & & \\
\hline Ateuchus squalidus (Fabricius, 1775) & ES & MG & RJ & $\mathrm{SP}$ & & & & & & \\
\hline Ateuchus striatulus (Preudhomme de Borre, 1886) & $\mathrm{GO}$ & MG & MS & MT & & & & & & \\
\hline Ateuchus vividus Germar, 1824 & $\mathrm{GO}$ & MG & MS & MT & & & & & & \\
\hline Canthidium aff. pinotoides & MS & MT & & & & & & & & \\
\hline Canthidium aff. barbacenicum & BA & $\mathrm{GO}$ & MG & MS & MT & PR & SP & & & \\
\hline Canthidium decoratum ( Perty, 1830) ${ }^{(2,4)}$ & BA & $\mathrm{GO}$ & MG & MS & MT & PR & SP & & & \\
\hline Canthidium dispar Harold, $1867^{(2)}$ & ES & MG & PR & RJ & $\mathrm{RS}$ & $\mathrm{SC}$ & SP & & & \\
\hline Canthidium humerale Germar, $1813^{(1)}$ & $\mathrm{AL}$ & $\mathrm{BA}$ & $\mathrm{PB}$ & PE & $\mathrm{SE}$ & PA & & & & \\
\hline Canthidium marseuli Harold, 1867 & MG & & & & & & & & & \\
\hline Canthon histrio (Lepeletier de Saint-Fargeau \& & BA & ES & GO & MG & MS & MT & $\mathrm{PE}$ & PR & $\mathrm{RS}$ & RJ \\
\hline Audinet-Serville, 1828) & $\mathrm{SC}$ & SP & & & & & & & & \\
\hline Canthon corpulentus Harold, 1868 (wrongly identified as C. lamproderes) & MT & MG & DF & & & & & & & \\
\hline Canthon rutilans cyanescens Harold, 1868 (many times identified as C. latipes) & PR & RS & RJ & $\mathrm{SC}$ & $\mathrm{SP}$ & & & & & \\
\hline Canthon linearis Schmidt, 1920 & $\mathrm{RR}$ & & & & & & & & & \\
\hline \multirow[t]{2}{*}{ Canthon lituratus (Germar, 1813) } & $\mathrm{AL}$ & $\mathrm{AM}$ & BA & $\mathrm{CE}$ & MA & PA & $\mathrm{PB}$ & PE & PI & $\mathrm{RN}$ \\
\hline & $\mathrm{RR}$ & SE & TO & & & & & & & \\
\hline Canthon mutabilis Lucas, 1857 & $\mathrm{BR}$ & & & & & & & & & \\
\hline Canthon nigripennis van Lansberge, $1874^{(1)}$ & AL & BA & PE & & & & & & & \\
\hline Canthon ornatus (often identified as Canthon bipunctatus Burmeister, 1973) & MS & MT & $\mathrm{PR}$ & RS & $\mathrm{SC}$ & & & & & \\
\hline Canthon ornatusornatus Redtennbacher, 1868 & GO & MG & MT & SP & & & & & & \\
\hline Canthon quadripunctatus Redtennbacher, 1868 & MG & RS & & & & & & & & \\
\hline Canthon rutilans Castelnau, 1840 & MG & SP & $\mathrm{RS}$ & & & & & & & \\
\hline \multirow[t]{2}{*}{ Canthon chalybaeus Blanchard, 1846} & $\mathrm{AL}$ & $\mathrm{BA}$ & ES & $\mathrm{GO}$ & MG & MS & MT & PE & PR & RS \\
\hline & $\mathrm{RJ}$ & $\mathrm{SC}$ & SE & $\mathrm{SP}$ & $\mathrm{TO}$ & & & & & \\
\hline Canthon virens Mannerheim, 1829 & MG & SP & & & & & & & & \\
\hline Chalcocopris hesperus (Olivier, 1789) & $\mathrm{BA}$ & ES & MG & $\mathrm{RJ}$ & SP & & & & & \\
\hline Coprophanaeus cyanescens (d'Olsoufieff, 1924) & $\mathrm{BA}$ & $\mathrm{GO}$ & MG & MS & MT & PA & $\mathrm{PE}$ & PR & SP & \\
\hline Coprophanaeus ensifer (Germar, 1821) & $\mathrm{AL}$ & $\mathrm{GO}$ & MG & MS & MT & $\mathrm{PB}$ & $\mathrm{PE}$ & & & \\
\hline Coprophanaeus horus (Waterhouse, 1891) ${ }^{(3)}$ & MG & $\mathrm{PR}$ & SP & & & & & & & \\
\hline Coprophanaeus pertyi (d'Olsoufieff, 1924) & AL & BA & $\mathrm{CE}$ & PB & PE & PI & $\mathrm{RN}$ & & & \\
\hline Coprophanaeus saphirinus (Sturm, 1826) & MG & $\mathrm{PR}$ & RJ & RS & $\mathrm{SC}$ & SP & & & & \\
\hline Coprophanaeus spitzi (Pessôa, 1934) & BA & $\mathrm{GO}$ & MG & MT & MS & PR & $\mathrm{RO}$ & SP & & \\
\hline Deltochilum elevatum (Castelnau, 1840)(2) & MG & $\mathrm{PR}$ & $\mathrm{RS}$ & RJ & $\mathrm{SC}$ & SP & & & & \\
\hline Diabroctis mimas (Linnaeus, 1758) & $\mathrm{BR}$ & & & & & & & & & \\
\hline Dichotomiu sassifer Eschscholtz, 1822 & $\mathrm{PR}$ & RS & $\mathrm{SC}$ & SP & & & & & & \\
\hline Dichotomius carbonarius Mannerhein, $1829^{(1)}$ & MG & MT & PR & & & & & & & \\
\hline Dichotomius crinicollis (Germar, 1824) & $\mathrm{AL}$ & $\mathrm{BA}$ & GO & MG & MT & PE & SE & SP & TO & \\
\hline Dichotomius fimbriatus (Harold, 1869) & ES & MG & $\mathrm{PR}$ & $\mathrm{RS}$ & RJ & $\mathrm{SC}$ & SP & & & \\
\hline Dichotomius fissus (Harold, 1867) & MG & PR & RJ & $\mathrm{SC}$ & SP & & & & & \\
\hline Dichotomius geminatus (Arrow, 1913) & $\mathrm{AL}$ & $\mathrm{BA}$ & $\mathrm{CE}$ & ES & MA & $\mathrm{PB}$ & PE & $\mathrm{RN}$ & SE & \\
\hline Dichotomius glaucus (Harold, 1869) & MS & MT & SP & & & & & & & \\
\hline Dichotomius longiceps (Taschenberg, 1870) ${ }^{(1)}$ & $\mathrm{GO}$ & MS & MT & MG & RO & SP & & & & \\
\hline Dichotomius lycas (Felsche, 1901) & $\mathrm{BA}$ & $\mathrm{GO}$ & MG & MS & MT & SP & TO & & & \\
\hline Dichotomius mormon (Ljungh, 1799) ${ }^{(1)}$ & $\mathrm{BA}$ & MG & PR & RJ & $\mathrm{SC}$ & SP & & & & \\
\hline Dichotomius opacipennis (Luederwaldt, 1931) & MS & MT & & & & & & & & \\
\hline Dichotomius semiaeneus (Germar, 1824) & MS & MT & GO & MG & SP & & & & & \\
\hline Dichotomius sexdentatus (Luederwaldt, 1925) & $\mathrm{BA}$ & $\mathrm{GO}$ & MA & MG & MS & MT & RO & & & \\
\hline Eurysternus caribaeus (Herbst, 1789) ${ }^{(1)}$ & $\mathrm{BR}$ & & & & & & & & & \\
\hline Eurysternus deplanatus Germar, 1824 & MG & RJ & RS & $\mathrm{SP}$ & & & & & & \\
\hline
\end{tabular}

Continuation... 
Table 3. Continuation...

\begin{tabular}{|c|c|c|c|c|c|c|c|c|c|c|}
\hline \multirow{2}{*}{$\begin{array}{l}\text { Species } \\
\text { Eurysternus hirtellus Dalman, 1824(1) }\end{array}$} & \multicolumn{10}{|c|}{ States ${ }^{(5)}$ with confirmed distribution } \\
\hline & $\mathrm{BA}$ & ES & MG & $\mathrm{PE}$ & $\mathrm{RJ}$ & & & & & \\
\hline Eurysternus jessopi Martinez, $1988^{(1)}$ & $\mathrm{BA}$ & $\mathrm{GO}$ & MG & MS & MT & SP & & & & \\
\hline Eurysternus nigrovirens Génier, 2009 & $\mathrm{GO}$ & MG & MS & MT & SP & & & & & \\
\hline Eurysternus parallelus Castelnau, 1840 & ES & MG & PR & RS & $\mathrm{RJ}$ & $\mathrm{SC}$ & SP & & & \\
\hline Eutrichillum hirsutum (Boucomont, 1928) & MS & MT & MG & PR & $\mathrm{RJ}$ & RS & $\mathrm{SC}$ & SP & & \\
\hline Genieridium bidens (Balthasar, 1938) & $\mathrm{BA}$ & ES & GO & MG & MS & MT & PR & $\mathrm{RJ}$ & SP & \\
\hline Gromphas inermis Harold, 1869 & $\mathrm{BA}$ & ES & MG & MS & MT & $\mathrm{PR}$ & $\mathrm{SC}$ & SP & RS & \\
\hline Ontherus azteca Harold, 1869 & $\mathrm{BR}$ & & & & & & & & & \\
\hline Ontherus dentatus Luederwaldt, 1930 & MS & MT & SP & & & & & & & \\
\hline Onthophagus bidentatus Drapiez, $1819^{(1)}$ & PA & & & & & & & & & \\
\hline Phanaeus kirbyi Vigors, 1825 & $\mathrm{BA}$ & $\mathrm{GO}$ & MS & MG & MT & SP & & & & \\
\hline Phanaeus palaeno Blanchard in Blanchard \& Brullé, 1845 & $\mathrm{DF}$ & BA & $\mathrm{GO}$ & MS & MG & MT & SP & & & \\
\hline Pseudocanthon aff. xanthurus (Blanchard in Blanchard \& Brullé, 1845) & ES & MA & MT & PA & PE & SP & & & & \\
\hline Sulcophanaeus menelas (Castelnau, 1840) & MG & $\mathrm{DF}$ & PR & RS & $\mathrm{SC}$ & SP & & & & \\
\hline Trichillum adjunctum Martínez, 1969 & $\mathrm{BA}$ & ES & GO & MG & MS & MT & PR & $\mathrm{RJ}$ & SP & TO \\
\hline Uroxys epipleuralis (Boucomont, 1928) & MS & $\mathrm{PR}^{(6)}$ & $\mathrm{RS}^{(6)}$ & $\mathrm{SC}^{(6)}$ & & & & & & \\
\hline
\end{tabular}

${ }^{(1)}$ Eventually collected on pasture. ${ }^{(2)}$ Eventually coprophagous. ${ }^{(3)}$ Natural fields up to 1,000 m. ${ }^{\left({ }^{4}\right)}$ Marker of Cerrado. ${ }^{(5)}$ States: MG, Minas Gerais; SP, São Paulo; PR, Paraná; SC, Santa Catarina; BA, Bahia; ES, Espírito Santo; GO, Goiás; MS, Mato Grosso; MT, Mato Grosso do Sul; RJ, Rio de Janeiro; RS, Rio Grande do Sul; AL, Alagoas; PB, Paraíba; PE, Pernambuco; SE, Sergipe; PA, Pará; DF, Distrito Federal; RR, Roraima; AM, Amazonas; CE, Ceará; MA, Maranhão; PI, Piauí; RN, Rio Grande do Norte; and TO, Tocantins. ${ }^{(6)}$ Unconfirmed records.

pastures surrounded by fragments of Atlantic Forest or in degraded areas from sea level up to about 1,300 m altitude (Almeida \& Louzada, 2009; Rossini \& Vazde-Mello, 2015) (Table 3 and Figure 1).

Coprophanaeus d'Olsoufieff, 1924 - a genus with 38 species, preferably necrophagous (Edmonds \& Zídek, 2010). Among these, six species are present in Cerrado and Caatinga phytophysiognomies considered open, where they can be found in natural and cultivated pastures. Coprophanaeus cyanescens (d'Olsoufieff, 1924) is considered an indicator of the biogeographic province of Chaco (Morrone, 2001), and Coprophanaeus horus (Waterhouse, 1891) was collected in grasslands in Cerrado areas above 1,000 $\mathrm{m}$ in altitude (Edmonds \& Zídek, 2010; Puker et al., 2014) (Table 3 and Figure 1).

Deltochilum Eschscholtz, 1822 - a genus with about 90 valid species (Génier, 2012). Deltochilum elevatum Castelnau, 1840 is associated with natural grasslands from Rio Grande do Sul to the Southeast, including grasslands of altitudes above $1,000 \mathrm{~m}$ in Minas Gerais (Table 3 and Figure 2). Other native species of the Cerrado and high altitude fields do not seem to be associated with excrement in the pastures.

Diabroctis Gistl, 1857 - a genus with only three species. Diabroctis mimas (Linnaeus, 1758) is collected in practically all of Brazil and in neighboring countries.
It is present from pastures and areas of Cerrado to areas with fragmented forest, in different successive stages of Atlantic Forest, up to $200 \mathrm{~m}$ altitude (Gillett et al., 2010) (Table 3 and Figure 2).

Dichotomius Hope, 1838 - a genus with roughly 170 valid species (Nunes \& Vaz-de-Mello, 2013), of which 17 are frequent in Brazilian pastures. In general, these species are important because of their high body mass and efficient burial activities of fecal masses in the soil. Two species are considered of great importance for pastures: Dichotomius bos (Blanchard, in Blanchard \& Brullé 1845), frequently cited as Dichotomius anaglypticus (Mannerheim, 1829) in the 1990s (Flechtmann et al., 1995a, 1995b, 1995c, 1995d), is in pastures throughout Brazil and in bordering countries (in and around the Chaco Depression); and Dichotomius nisus (Olivier, 1789), more widely distributed than $D$. bos, is present in the Brazilian Cerrado and Caatinga regions, entering areas of savannah, pastures, Amazonian riverbanks and in the Llanos of Colombia and Venezuela, up to the north of Roraima. The other 15 species have restricted distribution or a preference for forested environments and, although they frequent pastoral environments, are considered of medium and low importance for pastures (Tables 2 and 3, and Figures 2 and 3). 
Digitonthophagus Balthasar, 1959 - an AfroAsian genus with two species, currently in the process of taxonomic revision by François Génier.
A species of African origin, erroneously identified as Digitonthophagus gazella (Fabricius, 1787) (at the time considered in the genus Onthophagus), was

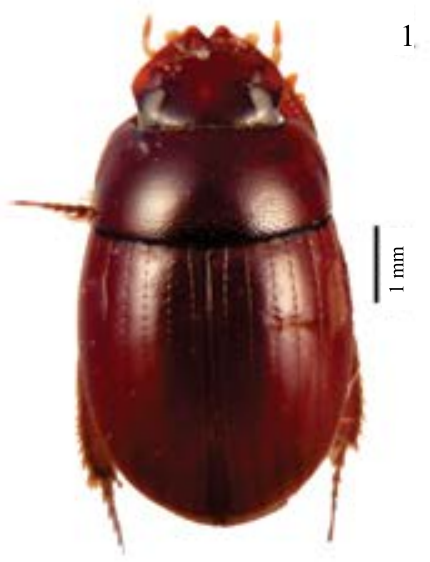

1
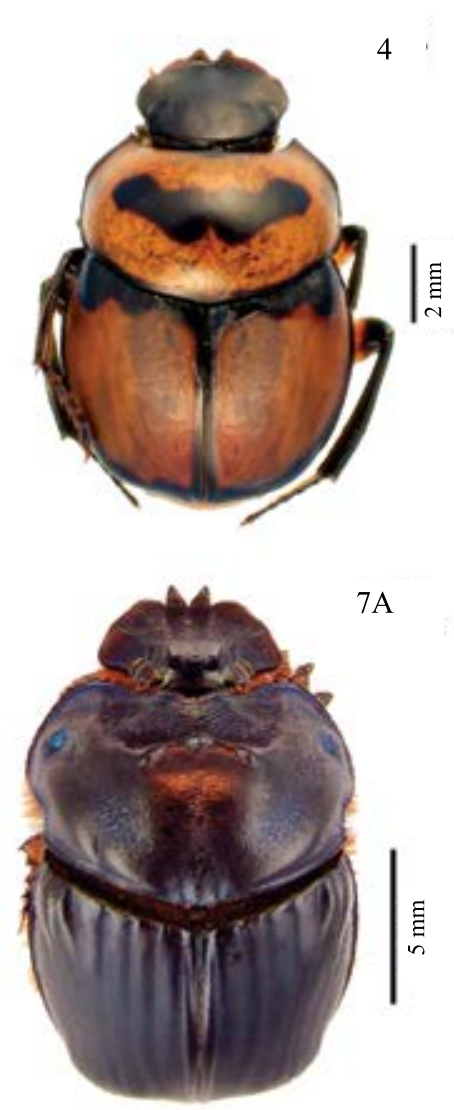
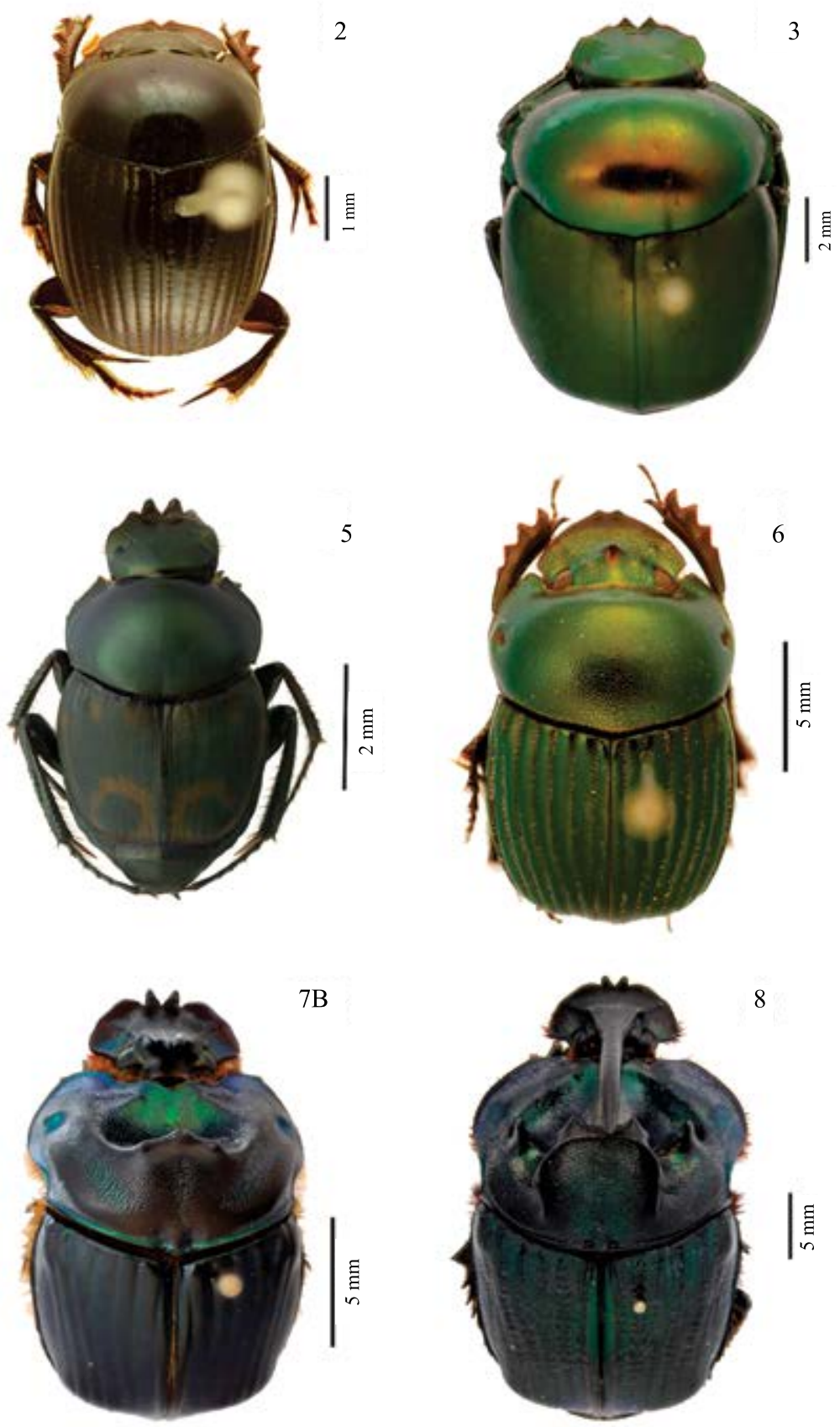

Figure 1. Dung beetles (Coleoptera: Scarabaeidae: Scarabaeinae) of Brazilian pastures: 1, Agamopus unguicularis (Harold, 1883); 2, Canthidium barbacenicum Preudhomme de Borre, 1886; 3, Canthon corpulentus Harold, 1868; 4, Canthon histrio (Lepeletier \& Serville, 1828); 5, Canthon lituratus (Germar, 1813); 6, Chalcocopris hesperus (Olivier, 1789); 7 A and B, Coprophanaeus cyanescens (d'Olsoufieff, 1924); 8, Coprophanaeus ensifer (Germar, 1821). Photos 1, 3, 4, and 6 by Rafael Vieira Nunes. 
introduced in Brazil in the 1980s, today it is present across almost the entire national territory (Bianchin et al., 1998), mainly associated with exotic pastures, and its occurrence is rare in areas of native vegetation. This species has a high rate of dispersion and fertility and establishes itself quickly in environments with
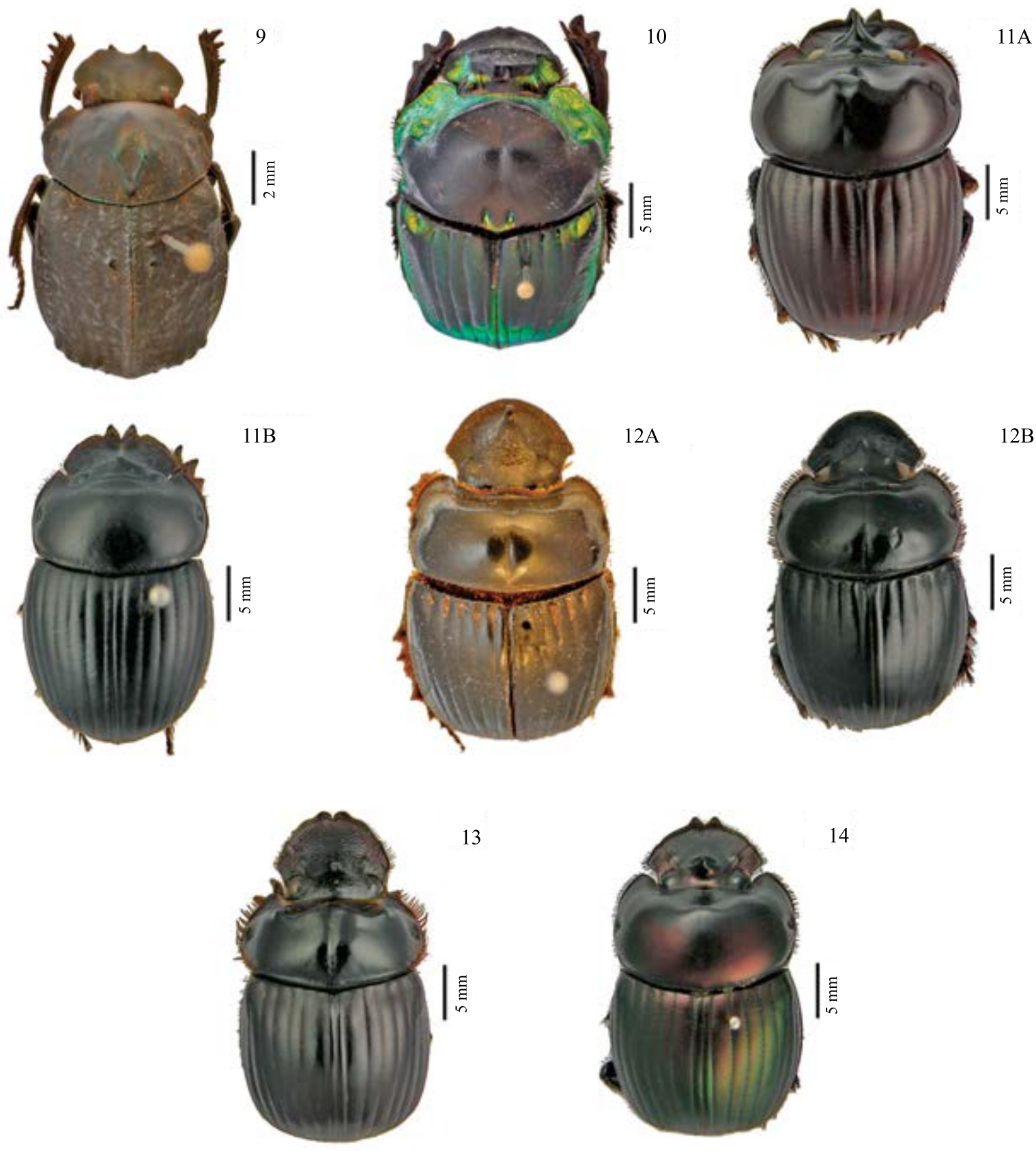

Figure 2. Dung beetles (Coleoptera: Scarabaeidae: Scarabaeinae) of Brazilian pastures: 9, Deltochilum elevatum (Castelnau, 1840); 10, Diabroctis mimas (Linnaeus, 1758); 11, Dichotomius bicuspis (Germar, 1824) male (A) and female (B); 12, Dichotomius bos (Blanchard, in Blanchard \& Brullé, 1845) male (A) and female (B); 13, Dichotomius fimbriatus (Harold, 1869); 14, Dichotomius lycas (Felsche, 1901). Photos by Rafael Vieira Nunes. 
high solar incidence, including savannas and pastures in the Amazon Region (Matavelli \& Louzada, 2008) (Figure 3). There is still uncertainty about the identification of this species present in Brazil, thus it was treated here as simply Digitonthophagus sp.
Eurysternus Dalman, 1824 - in the last review of the genus, conducted by Génier (2009), 53 species were recognized, six of them occurring in pastures in Brazil. Most of the species appear to be associated with forested environments, but with a tolerance to
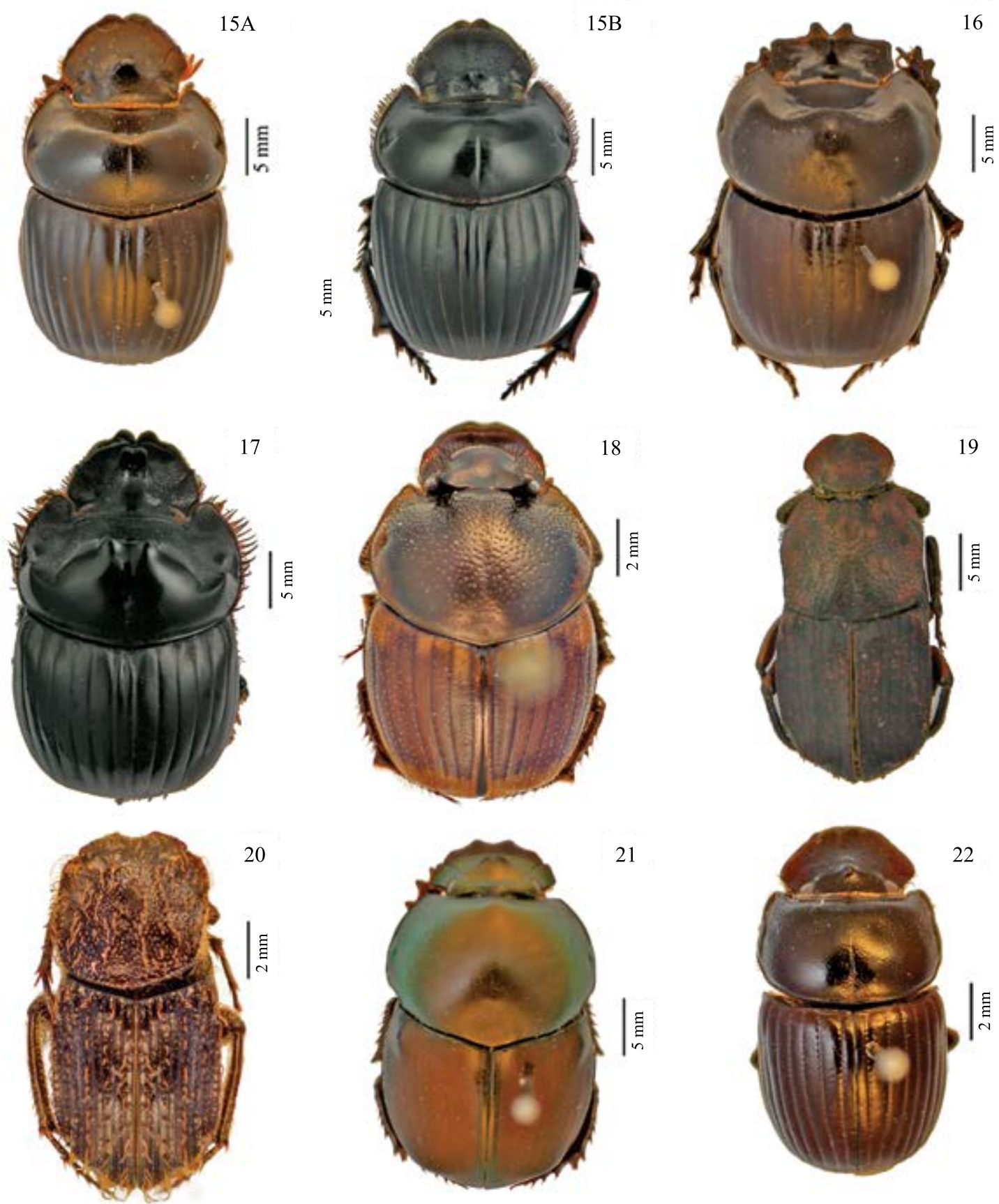

Figure 3. Dung beetles (Coleoptera: Scarabaeidae: Scarabaeinae) of Brazilian pastures: 15, Dichotomius nisus (Olivier, 1789), male (A) and female (B); 16, Dichotomius aff. quadraticeps, male; 17, Dichotomius semisquamosus (Curtis, 1845); 18, Digitonthophagus gazella (Fabricius, 1787), male; 19, Eurysternus caribaeus (Herbst, 1789); 20, Eurysternus nigrovirens Génier, 2009; 21, Gromphas inermis Harold, 1869; 22, Ontherus appendiculatus (Mannerheim 1829). Photos by Rafael Vieira Nunes. 
different degrees of anthropization, which allows their collection in pastures adjacent to fragments of forest (Table 3 and Figure 3).

Eutrichillum Martínez, 1969 - this genus presents three valid species (Vaz-de-Mello, 2008). Commonly found in pastures, the Eutrichillum hirsutum (Boucomont, 1928), a species of the Cerrado and Atlantic Forest (Table 3).

Genieridium Vaz-de-Mello, 2008 - of the seven species described in this genus, Genieridium bidens (Balthasar, 1938) and Genieridium cryptops (Arrow, 1913) are commonly caught in pastures in areas of the Cerrado and Chaco. Other species are also associated with natural grasslands and other nonforested phytophysiognomies of the Cerrado, but, in general, with natural vegetation (Vaz-de-Mello, 2008) (Table $3)$.

Ontherus Erichson, 1847 - in the most recent review of this genus, 59 species were recognized (Génier, 1996). The majority of them are distributed between the Southeast of Brazil and the Andes mountain range. The species Ontherus appendiculatus (Mannerheim, 1829) is considered of great importance for Brazilian pastures and is in the pastures and grasslands throughout the whole of Brazil. In the extreme north of the Amazon, this species also occurs in forested areas, but in other localities, it eventually frequents forests adjacent to pastures, small fragments of forest or secondary regeneration forests and sand dunes. Ontherus sulcator Fabricius, 1775 was also found in pastures and across the whole Chaco depression, where this species can also be considered of high importance. In other areas, in the rest of the country, O. sulcator is less common than $O$. appendiculatus (Table 3 , and Figures 3 and 4).

Onthophagus Latreille, 1802 - a genus with about 2,000 species distributed worldwide. The South American species are in urgent need of taxonomic revision. At least three species of the group hirculus are commonly present in the pastures. This group is currently under review. Onthophagus hirculus Mannerheim, 1829, considered to be of high importance for pastures, but is probably a number of species considered together. Originally described in the municipality of Diamantina, in the state of Minas Gerais, Brazil, this species belongs to a complex of closely related species that are distributed throughout grasslands and other phytophysiognomies, with low cover or without canopy cover, throughout the country, including clearings and the borders of Amazonian rivers (Table 2 and 3; Figure 4).

Phanaeus MacLeay, 1819 - a genus with 54 valid species (Edmonds \& Zídek, 2012). Two of them are inhabitants of the grasslands and savannas of Brazil and are eventually collected in cultivated pastures (Edmonds, 1994) (Table 3 and Figure 4).

Pseudocanthon Bates, 1887 - a genus with nine described species, two of them found in Brasil, but which seem to represent a complex of species in need of revision (Padilla-Gil \& Halffter, 2007; França et al., 2016). Only species associated with Pseudocanthon xanthurus (Blanchard, in Blanchard \& Brullé, 1845) are usually collected in pastures, clearings, natural fields, and other nonforested areas throughout the country (Table 3 and Figure 4).

Sulcophanaeus d'Olsoufieff, 1924 - a genus with 15 valid species (Arnaud, 2002). Only Sulcophanaeus menelas (Castelnau, 1840) can be found in pastures and forested environments in Brazil, from sea level up to 1,000 m altitude (Edmonds, 2000) (Table 3 and Figure 4).

Trichillum Harold, 1868 - to date, this genus has 11 valid species (Vaz-de-Mello, 2008). Unlike most other Scarabaeinae, species of this genus usually remain within the excrement, where they feed and lay their eggs freely (Vaz-de-Mello, 2008; López-Alarcón et al., 2009). The species Trichillum externepunctatum Preudhomme de Borre, 1880 is, on average, $3 \mathrm{~mm}$ in length and contributes to the destruction of bovine excrement in pastures, due to the high population that usually occurs in faecal pads. This species is considered of great importance for the pastures, it frequents the nonforested phytophysiognomies areas and anthropized environments - from the south of the Amazon to southern Uruguay - and is bordered to the west by the Andes. Trichillum externepunctatum is the most common species of the genus and coincides geographically with all the other species considered of great importance to the pastures (Vaz-de-Mello, 2008; López-Alarcón et al., 2009) (Table 3 and Figure 4).

Uroxys Westwood, 1842 - most of the 60 valid species are present in forested environments. It features size and ecological functions similar to those of the genus Trichillum (Vaz-de-Mello, 2008; Korasaki et al., 2012) (Table 3). 
From the survey conducted, a dichotomous key was developed to contribute to the identification of the genera and subgenera of dung beetles (Scarabaeidae, Scarabaeinae) which occur in the pastures of Brazil. In addition to the species cited and classified according to the degree of their importance, it is possible that on a regional scale, others may be collected, whether or not they frequent bovine feces. In order for these genera not
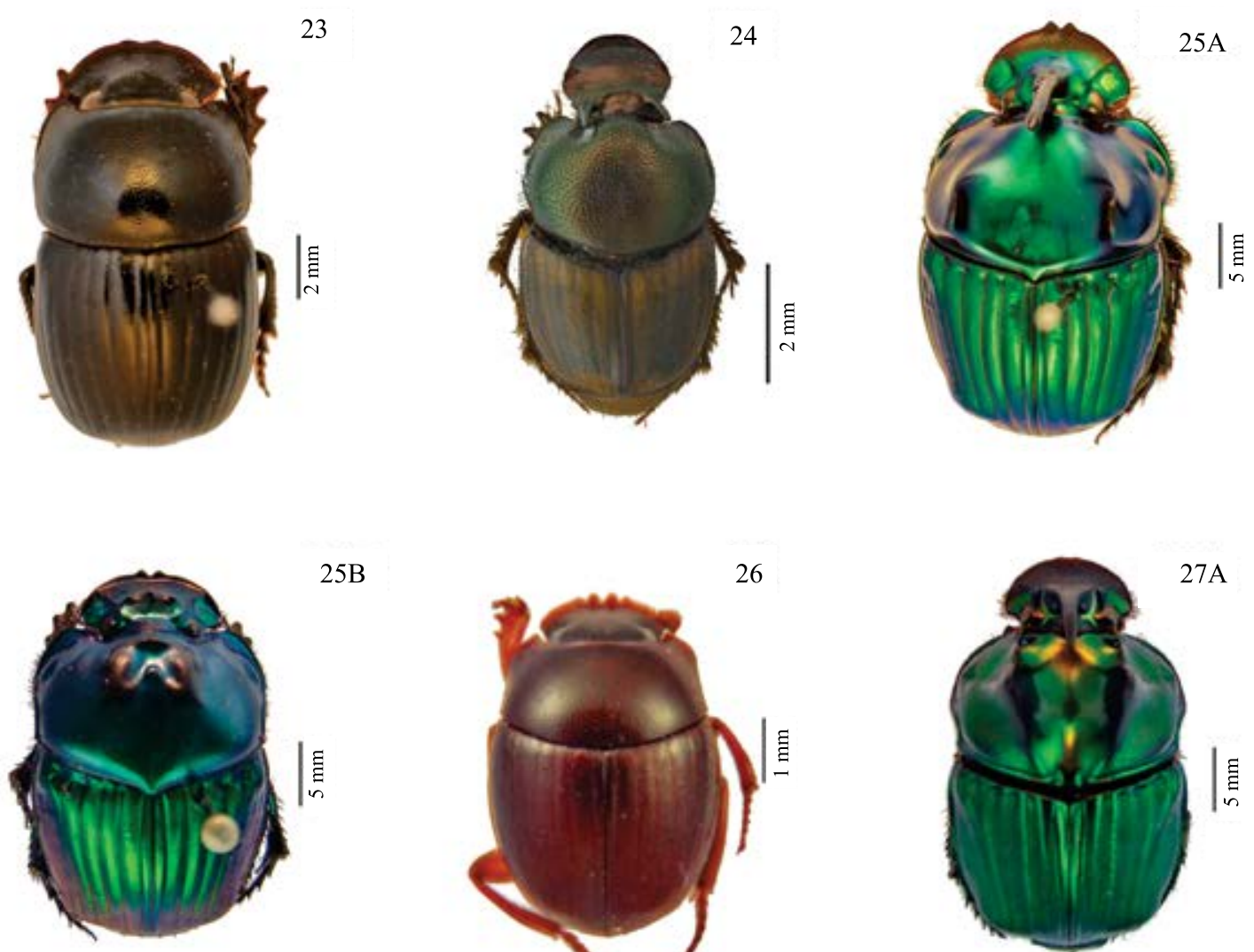

$25 \mathrm{~B}$
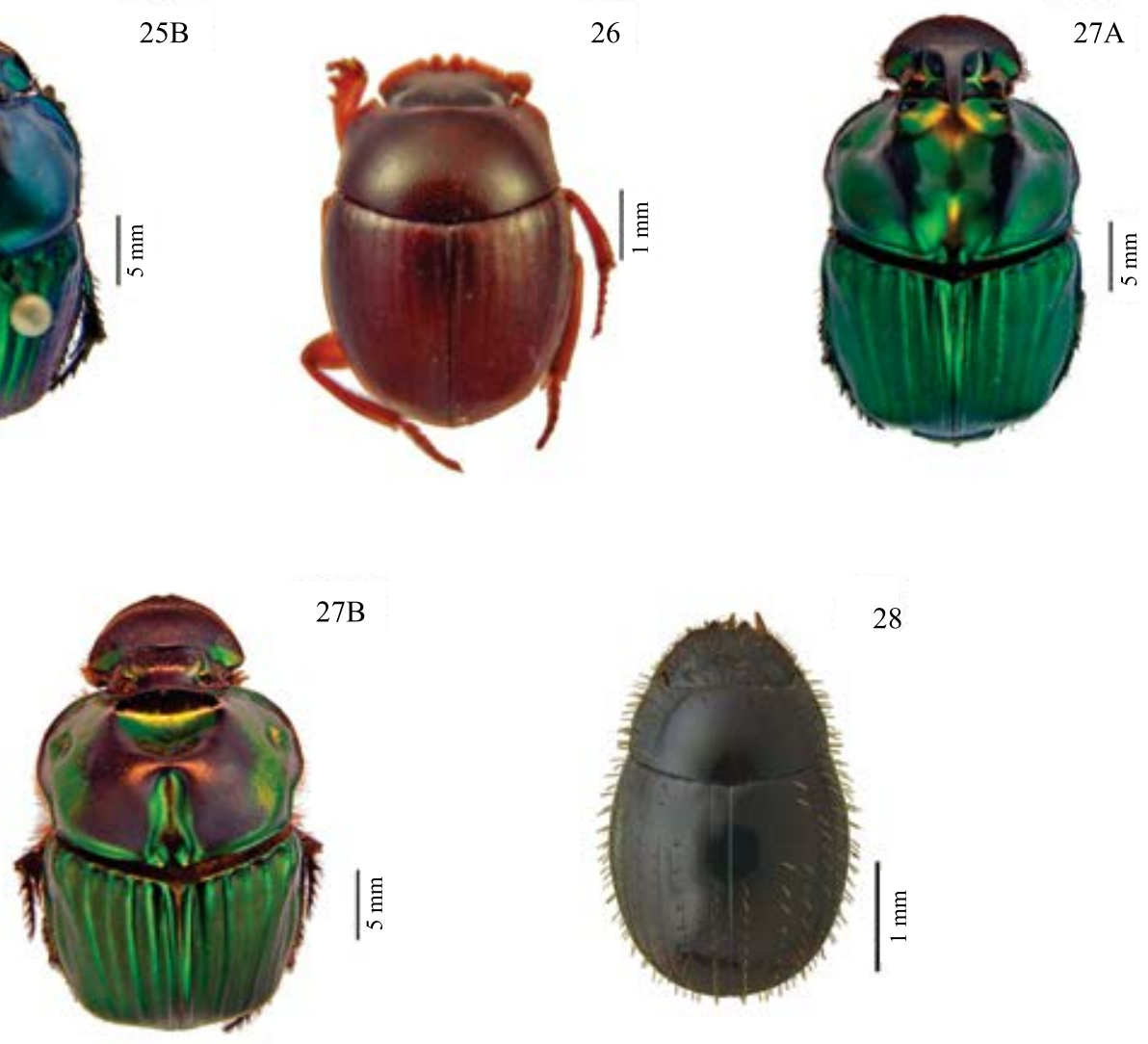

Figure 4. Dung beetles (Coleoptera: Scarabaeidae: Scarabaeinae) of Brazilian pastures: 23, Ontherus sulcator Fabricius, 1775; 24, Onthophagus aff. hirculus, male; 25, Phanaeus palaeno (Blanchard, in Blanchard \& Brullé, 1845), male (A) and female (B); 26, Pseudocanthon xanthurus (Blanchard, in Blanchard \& Brullé, 1845); 27, Sulcophanaeus menelas (Castenau, 1840), male (A) and female (B); 28, Trichillum externepunctatum Preudhomme de Borre, 1880. Photos 23 and 27 by Rafael Vieira Nunes. 
to be left unidentified or to be erroneously identified, all genera with this characteristic were added to the key as follows: Anisocanthon, Anomiopus, Besourenga, Bolbites, Degallieridium, Dendropaemon, Gromphas (Figure 3), Holocanthon, Isocopris, Malagoniella, Oxysternon, Sylvicanthon, and Vulcanocanthon.

1. Tip of mesoscutellum clearly visible between bases of elytra, exposed portion triangular, rounded, guttiform, or pentagonal. 2

1'. Mesoscutellum completely covered by elytra; tip, if exposed, minute, visible only under magnification (25 times or greater). 4

2 (1). Mesocoxae parallel to long axis of body and very widely separated, situated outside metasternum. Sides of body parallel. Eurysternus Dalman, 1824

2'. Mesocoxae perpendicular or oblique to long axis of body. Body rounded, anterior and posterior sides converging. 3

3 (2'). Pronotum with fine basal carina. Malagoniella (Megathopomima) Martínez, 1961

3'. Pronotum lacking basal margin. Malagoniella (Malagoniella) Martínez, 1961

4. Proleg with trochanto-femoral anterior pit (trochanto-femoral pit is situated in the apical border of trochanter). Length always less $7 \mathrm{~mm} .5$

4' (1'). Proleg lacking trochanto-femoral anterior pit. Variable length. 12

5 (4). Last abdominal sternite not grossly enlarged, all sternites clearly visible medially. 6

5'. Last abdominal sternite greatly expanded medially such that remaining sternites visible only laterally. 7

6 (5). Pronotum lacking longitudinal lateral sulcus. Pygidium divided by median discal transverse sulcus. Agamopus Bates, 1887

6'. Side of pronotum with deep longitudinal sulcus. Pygidium lacking median discal sulcus (sometimes basal sulcus sinuated and invading base of disc, but if so, the sulcus is clearly continuous to that one in the base). Uroxys Westwood, 1842

7 (5'). Pseudepipleuron expanded twice laterally, posterior expansion partially covering epipleuron and often angulate. Trichillum Harold, 1868

7'. Pseudepipleuron at most with single anterior expansion that never covers the epipleuron. Epipleuron sometimes excavated near metacoxa. 8
8 (7'). Pseudepipleuron abruptly narrowed posteriorly, distinctly angulate at the level of the metacoxa. 9

8'. Pseudepipleuron gradually narrowed posteriorly, not angulate at the level of the metacoxa. 10

9 (8). Clypeogenal suture clearly indicated and extending completely to the outer head border frontoclypeal suture distinct, at leastlaterally. Head border incised at junction with clypeogenal suture such that clypeus and gena appear separately rounded. Eutrichillum Martínez, 1969

9'. Frontoclypeal and clypeogenal sutures indistinct; head margin straight or slightly curved at juncture of clypeus and gena. Besourenga Vaz-de-Mello, 2008

10 (8'). Dorsal portion of eyes very small and narrow, separated by at least 10 times width. Maximum eyes width less than one-third length. Pseudoepipleuron not twisted longitudinally; with row of setae at least along posterior two-thirds. Length greater than $3.5 \mathrm{~mm}$. Genieridium Vaz-de-Mello, 2008

10'. Dorsal portion of eye separated less than seven times width. Maximum eyes width least half eye length. Pseudoepipleuron glabrous, twisted longitudinally, anterior one-half approximately vertical, posterior one-half approximately horizontal. Length less than 3 mm. 11

11 (10'). Hipomeron with posterior, longitudinal carinae. Elytral interstriae evenly flattened, discal interstriae with single row setigerous punctures. Leotrichillum Vaz-de-Mello, 2008

11'. Hipomeron lacking posterior carinae. Elytral interstriae distinctly convex apically. Discal interstriae with double row of punctures, only one row of which setigerous. Degallieridium Vaz-de-Mello, 2008

12 (4'). Length less than $13 \mathrm{~mm}$ and protibia with four teeth. Length of basal metatarsomere longer than that of following three tarsomeres combined; if subequal, then labial palpi with only two palpomeres (rarely third very reduced), the second one longer than the first. Metatarsus with five tarsomeres. Male, generally, with two horns at vertex; females with frontoclypeal and transverse carinae at vertex. 13

12'. Other characters variable. Length less than 13 $\mathrm{mm}$, protibia with four teeth or coloration dark.Length of basal metatarsomere less than combined length of following three tarsomeres; if subequal, then labial palpi with three distinct palpomeres, length of third palpomere at least one-half that of the second, and the 
second palpomere shorter than the first; or metatarsus with fewer than five tarsomeres. 14

13 (12). Length greater than $8 \mathrm{~mm}$, robust body with sides distinctly convex. Pronoto uniformly metallic coloration, pronotum evenly metallic, cupreous or greenish reflex, variegated elytra with brown spots. Hipomeron with oblique carina reaching lateral margin at anterior angle and forming rounded tooth in maleor sharp tooth in female; male with a strong internal apical tooth in protibia, strongly curved downwards at apex (African specie introduced). Digitonthophagus Balthasar, 1959

13'. Length usually less than $8 \mathrm{~mm}$; if greater, then different colored and sides of body parallel. Pronotal anterolateral margin without tooth next of anterior angle. Insertion of the longitudinal hypomeral carina exactly under the anterior angle, or without reaching the pronotal border. Onthophagus (Onthophagus) Latreille, 1807 15

14 (12'). Mesotarsus and metatarsus lacking claws.

14'. Mesotarsus and metatarsus with claws. 23

15 (14). Mesotarsus and metatarsus with 2-4 tarsomeres. Dendropaemon Perty, 1830 (with 7 subgenera not included here, usually rare and not coprophagous).

15'. Mesotarsus and metatarsus with five tarsomeres. 16

16 (15). Basal antennomere of antennal club not concave apically to fit apical antennomeres. Metepisternum simple, lacking tab. Gromphas Brullé, 1837

16'. Basal antennomere of antennal club larger and strongly concave apically, embracing second and third antennomeres. Dorsal edge of metepisternum with tab which coverslateral margin of elytron. 17

17 (16'). Clypeal margin deeply, acutely emarginate medially, emarginations producing two acute teeth that are separated from adjacent clypeal border by external emarginations. 18

17'. Clypeal margin lacking deep, acute emarginations; at most with two conspicuous median teeth. 20

18 (17). Very large beetles to $50 \mathrm{~mm}$ long, length rarely less than $25 \mathrm{~mm}$. Interstriae usually strongly sculptured (with transverse carinae or foveae). Coprophanaeus (Megaphanaeus) d'Olsoufieff, 1924
18'. Small to medium-sized beetles, length rarely over $25 \mathrm{~mm}$. Interstriae never strongly sculptured. 19

19 (18'). Male cephalic process laminate, never a tapering cylindrical horn. Hind wing with rounded notch in posterior margin near base. Dorsum usually mostly black with limited, muted metallic coloration, rarely conspicuously metallic. Coprophanaeus (Coprophanaeus) d'Olsoufieff, 1924

19'. Male cephalic process a simple, long tapering horn. Hind wing not notched. Dorsum usually metallic, never completely black. Coprophanaeus (Metallophanaeus) d'Olsoufieff, 1924

20 (17'). Head with transverse frontal carina, sometimes raised as pair of horns in male, in addition to frontoclypeal carina. Diabroctis Gistel, 1857

20 '. Head with single horn or carina, or bare. 21

21 (20'). Metasternum with long, dorsally curved, acute spiniform process extending between apex of procoxae. Posteromedian angle of pronotum prolonged between bases of elytra. Oxysternon (Oxysternon) Castelnau, 1840

21'. Metasternum simply angulate anteromedially, never spinose. 22

22 (21'). Anterior portion of circumnotal carina entire, not interrupted behind each eye. Sulcophanaeus d'Olsoufieff, 1924

22'. Anterior portion of circumnotal ridge interrupted behind each eye. Phanaeus (Notiophanaeus) Edmonds, 1994

23 (14'). Pronotum with two distinct, posteromedian fossae. Antennal club rounded, antennomeres progressively smaller apically. Head bearing transverse carina(e). Length 10-25 mm, metallic coloration. Bolbites Harold, 1868

23'. Posteromedian pronotal fossae absent. Other characters variable but not as in combination described above. 24

24 (23'). Body usually very cylindrical and metallic in colour. Tarsal claws reduced, straight or only weakly curved. Hipomeron convex or weakly concave, never deeply excavated anteriorly. Anomiopus Westwood, 1842

24'. Other characters variable. Tarsal claws large, strongly curved, falciform or angulate; if only weakly developed, then either hipomeron deeply excavated anteriorly. 25

25 (24'). Mesotibia and metatibia strongly widened apically, or only weakly and gradually so. 26

Pesq. agropec. bras., Brasília, v.52, n.6, p.401-418, jun. 2017 DOI: 10.1590/S0100-204X2017000600004 
25'. Mesotibia and usually also metatibia abruptly widened apically. 39

26 (25). Apex of some elytral interstriae with short carinae or tubercles. 27

26'. Elytral interstriae lacking apical carinae or tubercles, at most with one lateral almost complete elytral carina. 30

27 (26). Length greater than $15 \mathrm{~mm}$, body elongate. Male with well-defined tubercles in the midle of elytral disc. Metallic reddish or bluish color. Ninth elytral interstria (on pseudepipleuron) lacking carina, or with an inconspicuous carina. Deltochilum (Calhyboma) Kolbe, 1893

27'. Large beetle and metallic reddish, so elytral interstriae costiform. Carina on ninth interstriae (pseudepipleuron) present on at least anterior threefourths of interstriae. 28

28 (27'). Elytra flattened dorsally, head soor lengthier than wide. Deltochilum (Aganhyboma) Kolbe, 1893

28'. Elytra distinctly convex, head wider than long. 29

29 (28'). Length less than $20 \mathrm{~mm}$. Metasternum lacking posterior tubercles. Clypeus bidentate. Deltochilum (Deltohyboma) Lane, 1946

29'. Length usually greater than $15 \mathrm{~mm}$. Metasternal disc bituberculate posteriorly. Clypeus quadridentate. Deltochilum (Hybomidium) Shipp, 1897

30 (26'). Posterior margin of head not margined between eyes. Mesosternum relatively long, not narrowed medially, completely horizontal. 31

30'. Posterior margin of head clearly and completely margined between eyes. Mesosternum shorter medially than laterally, or positioned vertically and weakly visible from below. 33

31 (30). Body elongate and dorsoventrally flattened. Tarsal claws usually angulate basally. Clypeus quadridentate. Pseudocanthon Bates, 1887

31'. Body rounded. Tarsal claws simple, not angulate basally. 32

32 (31'). Clypeus widely emarginate and bidentate, teeth are short and wellspaced. Dorsal portion of eyes very narrow, inner eye margin bordered by fine carina. Lateral pronotal margins rounded, not angulate. Protibia with three large teeth along distal one-half of lateral margin. Length of tarsomere 1 of mesotarsus and metatarsus about equal to that of tarsomere 2 . Pygidium and propygidium not separated by carina. Vulcanocanthon Pereira \& Martínez, 1960
32'. Clypeus prolonged medially, quadridentate or two small teeth too close together. Dorsal portion of eyes large, rounded, inner margin not bordered. Lateral pronotal margins angulate medially. Protibial teeth small, concentrated in apical one-third or one-fourth of tibia. Tarsomere 1 of mesotarsus and metatarsus shorter than tarsomere 2. Pygidium and propygidium separated by fine carina. Sylvicanthon Halffter \& Martínez, 1977

33 (30'). Mento completely divided longitudinally. Holocanthon Martínez \& Pereira, 1956

33'. Mentum not completely divided, at most with deep U-shaped or V-shaped emargination. 34

34 (33'). Dorsum (especially prothorax) with irregular sculpturing (mosaic of smooth, sericeous and micro granular areas, irregular ill-defined elevations and depressions) or with well-defined prothoracic tubercles. Mentum not emarginate, anterior margin straight or nearly so. Anisocanthon Martínez \& Pereira, 1956

34'. Pronotum with evenly distributed sculpturing, at most with posteromedian depression, never with tubercles. Mentum deeply emarginate. 35

35 (34'). Ventral surface of metafemur not margined anteriorly. Pygidium and propygidium separated by transverse carina. Canthon (Glaphyrocanthon) Martínez, 1948

35'. Ventral surface of metafemur with fine anterior margin or pygidium and propygidium not separated by transverse carina. 36

36 (35'). Pygidium and propygidium not separated by transverse carina. Canthon sensu lato Hoffmannsegg, 1817

36'. Pygidium and propygidium at least partially separated by transverse carina. 37

37 (36'). Metatibia of male very curved, apex obliquely truncated with inner angle spinose, extending beyond insertion of metatarsus. Metatibia of female usually much less curved than male, apex straight or slightly oblique, inner angle not prolonged. Pronotum with posteromedian depression; adjacent area of elytra similarly depressed. Canthon (Pseudepilissus) Martínez, 1954

37'. Metatibia same in both sexes, straight or curved, inner angle never spinose. 38

38 (37'). Anterior margin of profemur with one or several denticles, or excavated anteriorwith several 
denticles in a bottom. Canthon (Francmonrosia) Pereira \& Martínez, 1959

38'. Profemur lacking of teeth neither denticles, nor excavated anterior. Canthon (Canthon) Hoffmannsegg, 1817

39 (25'). Hipomeron deeply excavated anteriorly, excavation shaped posteriorly as vertical wall topped by strong carina.Inner apicalangle of protibia $\sim 90^{\circ}$ or acute, edge of apical tooth continuous (not forming angle) with apical truncation. Ateuchus Weber, 1801

39'. Propleura only weakly excavated anteriorly, excavation not clearly defined posteriorly. Inner apical angle of protibia obliquely truncate $\left(>90^{\circ}\right)$; if approximately $90^{\circ}$ or slightly acute, then edge ofapical tooth forming angle with margin of apical truncation. 40

40 (39'). Length usually less than $10 \mathrm{~mm}$. Inner apical angle of protibia $\sim 90^{\circ}$ or acute. Mesosternum usually very short, positioned almost vertically. Clypeal process usually absent, sometimes indicated by feeble longitudinal ridge or transverse carina. Metasternum usually convex. Dilation of mesotibia and metatibia resulting from curvature of inner margin only, outer margin straight. 41

40 '. Length usually greater than $10 \mathrm{~mm}$. Inner apical angle of protibia usually greater than $90^{\circ}$. Mesosternum very well developed, horizontal. Clypeal process bifurcate tubercle or transverse ridge with or without median angle or tubercle. Metasternum usually flat. Dilation of mesotibia and metatibia resulting from curvature of both inner and outer margins. 42

41 (40). Posterior margin of pronotum almost always paralleled by row of punctures distinctly larger than any adjacent punctures on pronotum, sometimes interrupted medially. Canthidium (Canthidium) Erichson, 1847

41'. Pronotum lacking distinct row of larger punctures along posterior margin. Canthidium (Eucanthidium) Martínez \& Halffter, 1986

42 (40'). Body elongated. Ventromedial carina of protibia with intervening setae in basal third. Abdomen straight in lower side view, very short, frequently with smaller ventral length similar or less than width of the metacoxa. Clypeal process transverse, obtusely triangular, never with teeth. Ontherus (Ontherus) Erichson, 1847

42'. Body oval, rounded and strongly convex. Ventromedial carina of protibia only apically intervening setae. Abdomen convex in lower side view, normal length, over twice the width of the metacoxa. Clypeal process usually conical with bifurcate apex, sometimes embedded in longitudinal carina; rarely configured otherwise, but never a simple transverse ridge. 43

43(42'). Antenna with eight antennomeres. Isocopris Pereira \& Martínez, 1960

43'. Antenna with nine antennomeres. 44

44. Clypeal margin with single median tooth. Dichotomius (Homocanthonides) Luederwaldt, 1929

44'. Clypeal margin rounded, feebly emarginate or bidentate. 45

45. Clypeal margin rounded or weakly emarginated, if bidentate, then teeth minute, not margined. Dichotomius (Dichotomius) Hope, 1838

45. Clypeus distinctly bidentate, teeth usually marginate. 46

46 (45'). Margin of head usually angled at junction of clypeus and gena. Metasternal pilosity usually short and scattered or rarelyabsent. Last abdominal sternite of female usually prolonged beneath apex of Pygidium or raised medially. Dichotomius (Selenocopris) Burmeister, 1846

46'. Head margin evenly rounded, not angled at clypeogenal junction. Metasternal pilosity usually abundant. Last abdominal sternite of female never prolonged beneath apex of pygidium, neither raised medially. Dichotomius (Luederwaldtinia) Martínez, 1951

\section{Conclusions}

1. The dichotomus key of dung beetles genera and subgenera contributes to identify the insects that occur in Brazilian pastures and their potential to the biological control of parasites that develop in bovine dung pats.

2. Brazilian pastures registered 20 genera and 76 dung beetles species, among which Dichotomius bos, Dichotomius nisus, Trichillum externepunctatum, Ontherus appendiculatus, Onthophagus aff. hirculus, and Digitonthophagus sp. were considered the most frequent, widely distributed, abundant, and important.

\section{Acknowledgments}

To Conselho Nacional de Desenvolvimento Científico e Tecnológico (CNPq), to Coordenação de 
Aperfeiçoamento de Pessoal de Nível Superior (Capes), and to Fundação de Amparo à Pesquisa do Estado de Mato Grosso (Fapemat), for financial support.

\section{References}

AIDAR, T.; KOLLER, W.W.; RODRIGUES, S.R.; CORRÊA, A.M.; SILVA, J.C.C. da; BALTA, O. dos S.; OLIVEIRA, J.M. de; OLIVEIRA, V.L. de. Besouros coprófagos (Coleoptera: Scarabaeidae) coletados em Aquidauana, MS, Brasil. Anais da Sociedade Entomológica do Brasil, v.29, p.817-820, 2000. DOI: 10.1590/S0301-80592000000400023.

ALMEIDA, S. da S.P. de; LOUZADA, J.N.C. Estrutura da comunidade de Scarabaeinae (Scarabaeidae: Coleoptera) em fitofisionomias do Cerrado e sua importância para a conservação. Neotropical Entomology, v.38, p.32-43, 2009. DOI: 10.1590/ S1519-566X2009000100003.

ALMEIDA, S.; LOUZADA, J.; SPERBER, C.; BARLOW, J. Subtle land-use change and tropical biodiversity: dung beetle communities in Cerrado grasslands and exotic pastures. Biotropica, v.43, p.704-710, 2011. DOI: $10.1111 / \mathrm{j} .1744-$ 7429.2011.00751.x

ARNAUD, P. Les coléoptères du monde. Volume 28: Phanaeini. Canterbury: Hillside Books, 2002. 151p.

BIANCHIN, I.; ALVES, R.G.O.; KOLLER, W. Efeito de carrapaciticidas/inseticidas "pour on" sobre adultos de besouro coprófago africano Onthophagus gazella Fabr. (Coleoptera: Scarabaeidae). Anais da Sociedade Entomológica do Brasil, v.27, p.275-279, 1998. DOI: 10.1590/S0301-80591998000200014.

COSTA, C.M.Q. da; SILVA, F.A.B.; FARIAS, Â.I. de; MOURA, R. de C. de. Diversidade de Scarabaeinae (Coleoptera, Scarabaeidae) coletados com armadilha de interceptação de vôo no Refúgio Ecológico Charles Darwin, Igarassu-PE, Brasil. Revista Brasileira de Entomologia, v.53, p.88-94, 2009. DOI: 10.1590/ S0085-56262009000100021.

EDMONDS, W.D. Revision of Phanaeus Macleay, a new world genus of Scarabaeinae dung beetles (Coleoptera: Scarabaeidae, Scarabaeinae). Contributions in Science, n.443, p.1-105, 1994.

EDMONDS, W.D. Revision of the Neotropical dung beetle genus Sulcophanaeus (Coleoptera: Scarabaeidae: Scarabaeinae). Folia Heyrovskyana, v.6, p.1-60, 2000. Supplementum.

EDMONDS, W.D.; ZIDEK, J. A taxonomic review of the neotropical genus Coprophanaeus Olsoufieff, 1924 (Coleoptera: Scarabaeidae, Scarabaeinae). Insecta Mundi, v.129, p.1-111, 2010.

EDMONDS, W.D.; ZÍDEK, J. Taxonomy of Phanaeus revisited: revised keys to and comments on species of the New World dung beetle genus Phanaeus MacLeay, 1819 (Coleoptera: Scarabaeidae: Scarabaeinae: Phanaeini). Insecta Mundi, v.274, p.1-108, 2012.

FLECHTMANN, C.A.H.; RODRIGUES, S.R. Insetos fimícolas associados a fezes bovinas em Jaraguá do Sul/SC. 1. Besouros coprófagos (Coleoptera, Scarabaeidae). Revista Brasileira de Entomologia, v.39, p.303-309, 1995.
FLECHTMANN, C.A.H.; RODRIGUES, S.R.; ARAÚJO, S.D. de; WENZEL, R.L. Levantamento de insetos fimícolas em Ilha Solteira, São Paulo, Brasil. Revista Brasileira de Entomologia, v.39, p.115-120, 1995a.

FLECHTMANN, C.A.H.; RODRIGUES, S.R.; COUTO, H.T.Z. do. Controle biológico da mosca-dos-chifres (Haematobia irritans irritans) em Selvíria, Mato Grosso do Sul. 4. Comparação entre métodos de coleta de besouros coprófagos (Scarabaeidae). Revista Brasileira de Entomologia, v.39, p.259-276, 1995b.

FLECHTMANN, C.A.H.; RODRIGUES, S.R.; GASPARETO, C.L. Controle biológico da mosca-dos-chifres (Haematobia irritans irritans) em Selvíria, Mato Grosso do Sul. 5. Seleção de besouros coprófagos. Revista Brasileira de Entomologia, v.39, p.277-286, 1995c.

FLECHTMANN, C.A.H.; RODRIGUES, S.R.; SENO, M.C.Z. Controle biológico da mosca-dos-chifres (Haematobia irritans irritans) em Selvíria, Mato Grosso do Sul. 3. Levantamento de espécies fimícolas associadas à mosca. Revista Brasileira de Entomologia, v.39, p.249-258, 1995d.

FRANÇA, F.M.; KORASAKI, V.; LOUZADA, J.; VAZ-DEMELLO, F.Z. First report on dung beetles in intra-Amazonian savannahs in Roraima, Brazil. Biota Neotropica, v.16, p.34-38, 2016. DOI: 10.1590/1676-0611-BN-2015-0034.

GÉNIER, F. A new species and notes on the subgenus Deltochilum (Deltochilum) Eschscholtz, 1822 (Coleoptera: Scarabaeidae: Scarabaeinae: Deltochilini). Zootaxa, v.3357, p.25-36, 2012.

GÉNIER, F. A revision of the Neotropical genus Ontherus Erichson (Coleoptera, Scarabaeidae, Scarabaeinae). The Memoirs of the Entomological Society of Canada, v.128, p.3-170, 1996. DOI: $10.4039 /$ entm128170fv.

GÉNIER, F. Le genre Eurysternus Dalman, 1824 (Scarabaeidae: Scarabaeinae: Oniticellini), révision taxonomique et clés de détermination illustrées. Sofia: Pensoft, 2009. 430p. (Pensoft series faunistica, 85).

GÉNIER, F.A; MORETTO, P. Digitonthophagus Balthasar, 1959: taxonomy, systematics, and morphological phylogeny of the genus revealing an African species complex (Coleoptera: Scarabaeidae: Scarabaeinae). Zootaxa, v.4248, p.1-110, 2017. DOI: 10.11646/ zootaxa.4248.1.1.

GILLETT, C.P.D.T.; GILLETT, M.P.T.; GILLETT, J.E.D.T.; VAZDE-MELLO, F.Z. Diversity and distribution of the scarab beetle tribe Phanaeini in the northern states of the Brazilian Northeast (Coleoptera: Scarabaeidae: Scarabaeinae). Insecta Mundi, v.118, p.1-20, 2010.

HALFFTER, G. Historical and ecological factors determining the geographical distribution of beetles (Coleoptera: Scarabaeidae: Scarabaeinae). Folia Entomológica Mexicana, v.82, p.195-238, 1991.

HALFFTER, G.; MARTÍNEZ, A. Revisión monográfica de los Canthonina americanos. (Coleoptera, Scarabaeidae) (3a. Parte). Revista de La Sociedad Mexicana de Historia Natural, v.29, p.226-241, 1968.

HALFFTER, G.; MATTHEWS, E.G. The natural history of dung beetles of the subfamily Scarabaeinae (Coleoptera: 
Scarabaeidae). México, DF: Sociedad Mexicana de Entomología, 1966. 312 p. (Folia Entomológica Mexicana, n. 12-14).

KOLLER, W.W.; GOMES, A.; RODRIGUES, S.R.; ALVES, R.G. de O. Besouros coprófagos (Coleoptera: Scarabaeidae) coletados em Campo Grande, MS, Brasil. Anais da Sociedade Entomológica do Brasil, v.28, p.403-412, 1999. DOI: 10.1590/ S0301-80591999000300004.

KOLLER, W.W.; GOMES, A.; RODRIGUES, S.R.; GOIOZO, P.F.I. Scarabaeidae e Aphodiidae coprófagos em pastagens cultivadas em área do cerrado sul-mato-grossense. Revista Brasileira de Zoociências, v.9, p.81-93, 2007.

KORASAKI, V.; LOPES, J.; BROWN, G.G.; LOUZADA, J. Using dung beetles to evaluate the effects of urbanization on Atlantic Forest biodiversity. Insect Science, v.20, p.393-406, 2012. DOI: 10.1111/j.1744-7917.2012.01509.x.

LOPES, J.; KORASAKI, V.; CATELLI, L.L.; MARÇAL, V.V.M; NUNES, M.P.B.P. A comparison of dung beetle assemblage structure (Coleoptera: Scarabaeidae: Scarabaeinae) between an Atlantic Forest fragment and adjacent abandoned pasture in Paraná, Brazil. Zoologia, v.28, p.72-79, 2011. DOI: 10.1590/ S1984-46702011000100011.

LÓPEZ-ALARCÓN, D.; HALFFTER, G.; VAZ-DE-MELLO, F.Z. Nesting behavior in Trichillum Harold, 1868 and related gGenera (Coleoptera: Scarabaeidae: Scarabaeinae: Ateuchini: Scatimina): primitive process or a loss of nidification? The Coleopterists Bulletin, v.63, p.289-297, 2009. DOI: 10.1649/1132.1.

LOUZADA, J.N.C.; SILVA, P.R.C. e. Utilisation of introduced Brazilian pastures ecosystems by native dung beetles: diversity patterns and resource use. Insect Conservation and Diversity, n.2, p.45-52, 2009. DOI: 10.1111/j.1752-4598.2008.00038.x.

MARCHIORI, C.H. Espécies de Scarabaeidae (Insecta: Coleoptera) coletadas em fezes bovinas e carcaça de suínos em Itumbiara, Goiás, Brasil. Pesquisa Agropecuária Tropical, v.30, p.1-4, 2000.

MARCHIORI, C.H.; CALDAS, E.R.; ALMEIDA, K.G.S. Succession of Scarabaeidae on bovine dung in Itumbiara, Goiás, Brazil. Neotropical Entomology, v.32, p.172-176, 2003. DOI: 10.1590/S1519-566X2003000100029.

MARCHIORI, C.H.; OLIVEIRA, Â.T. de; LINHARES, A.X. Artrópodes associados a massas fecais bovinas no sul do Estado de Goiás. Neotropical Entomology, v.30, p.19-24, 2001. DOI: 10.1590/S1519-566X2001000100004.

MATAVELLI, R.A.; LOUZADA, J.N.C. Invasão de áreas de savana intra-amazônicas por Digitonthophagus gazella (Fabricius, 1787) (Insecta: Coleoptera: Scarabaeidae). Acta Amazonica, v.38, p.153-158, 2008. DOI: 10.1590/S0044-59672008000100017.

MENDES, J.; LINHARES, A.X. Coleoptera associate with undisturbed cow pats in pastures in Southeastern Brazil. Neotropical Entomology, v.35, p.715-723, 2006. DOI: 10.1590/ S1519-566X2006000600001.

MORRONE, J.J. Biogeografía de América Latina y el Caribe. Zaragoza: Sociedad Entomológica Aragones, 2001. 148p. (SEA. Manuales \& tesis, 3).
NORIEGA, J.A.; HORGAN, F.G.; LARSEN, T.H.; VALENCIA, G. Records of an invasive dung beetle species, Digitonthophagus gazella (Fabricius, 1787) (Coleoptera: Scarabaeidae), in Peru. Acta Zoológica Mexicana, v.26, p.451-456, 2010.

NICHOLS, E.; SPECTOR, S.; LOUZADA, J.; LARSEN, T.; AMEZQUITA, S.; FAVILA, M.E. Ecological functions and ecosystem services provided by Scarabaeinae dung beetles. Biological Conservation, v.141, p.1461-1474, 2008. DOI: 10.1016/j.biocon.2008.04.011.

NUNES, R.V.; VAZ-DE-MELLO, F.Z. New brachypterous species of Dichotomius Hope, with taxonomic notes in the subgenus Luederwaldtinia Martínez (Coleoptera: Scarabaeidae: Scarabaeinae). Zootaxa, v.3609, p.411-420, 2013. DOI: 10.11646/ zootaxa.3609.4.3.

OLIVEIRA, G.P. de; SILVA, A.L. da; MENDES, J.; TAVARES, L.N.J. Insetos associados a fezes de bovinos na região de São Carlos, São Paulo. Ciência Agronômica, v.27, p.39-47, 1996.

PADILLA-GIL, D.N.; HALFFTER, G. Biogeography of the areas and Canthonini (Coleoptera: Scarabaeidae) of dry tropical forest in Mesoamerica and Colombia. Acta Zoológica Mexicana, v.23, p.73-108, 2007

PEREIRA, C.C.A.; CHAVES, D.P.; KOLLER, W.W.; CONCEIÇÃO, W.L.F.; RODRIGUES, S.R.; GOMES, A.; COSTA JÚNIOR, L.M. Ocorrência de coleópteros Scarabaeidae (coprófagos e necrófagos), Aphodiidae, Histeridae e Hydrophilidae em fezes bovinas na Ilha de São Luís, Maranhão, Brasil - resultados preliminares. Revista Universidade Rural, v.23, p.327-328, 2003.

PUKER, A.; CORREA, C.M.A.; KORASAKI, V. Deltochilini and Phanaeini dung beetles (Coleoptera: Scarabaeidae: Scarabaeinae) in introduced and native ecosystems of Brazil. Journal of Natural History, v.49, p.1-15, 2014. DOI: 10.1080/00222933.2014.908969.

RIDSDILL-SMITH, T.J.; EDWARDS, P.B. Biological control: ecosystem functions provided by dung beetles. In: SIMMONS, L.W.; RIDSDILL-SMITH, T.J. (Ed.). Ecology and evolution of dung beetles. Oxford: Wiley-Blackwell, 2011. p.245-264. DOI: 10.1002/9781444342000.ch12.

RODRIGUES, S.; FLECHTMANN, C.A.H. Aspectos biológicos de Canthon lituratus (Germar, 1813) e Canthidium (Canthidium) megathopoides Boucomont, 1928 (Coleoptera, Scarabaeidae). Acta Zoológica Mexicana, n.70, p.1-12, 1997.

RODRIGUES, S.R.; MARCHINI, L.C. Besouros Coprófagos (Coleoptera; Scarabaeidae) coletados em Piracicaba, SP. Scientia Agricola, v.55, p.53-58, 1998. DOI: 10.1590/S010390161998000100010.

RODRIGUES, S.R.; BARROS, A.T.M. de; PUKER, A.; TAIRA, T.L. Diversidade de besouros coprófagos (Coleoptera, Scarabaeidae) coletados com armadilha de interceptação de voo no Pantanal Sul-Mato-Grossense, Brasil. Biota Neotropica, v.10, p.123-127, 2010. DOI: 10.1590/S1676-06032010000200015.

RONQUI, D.C.; LOPES, J. Composição e diversidade de Scarabaeoidea (Coleoptera) atraídos por armadilha de luz em área rural no norte do Paraná, Brasil. Iheringia. Série Zoologia, v.96, p.103-108, 2006. DOI: 10.1590/S0073-47212006000100018. 
ROSSINI, M.; VAZ-DE-MELLO, F.Z. A review of the genus Chalcocopris Burmeister, 1846 (Coleoptera: Scarabaeidae: Scarabaeinae), with description of a new species. Zootaxa, v.3920, p.291-300, 2015. DOI: 10.11646/zootaxa.3920.2.5.

SCHEFFLER, P.Y. Dung beetle (Coleoptera: Scarabaeidae) diversity and community structure across three disturbance regimes in eastern Amazonia. Journal of Tropical Ecology, v.21, p.9-19, 2005. DOI: 10.1017/S0266467404001683.

SCHIFFLER, G.; VAZ-DE-MELLO, F.Z.; AZEVEDO, C.O. Scarabaeidae s.str. (Coleoptera) do Delta do Rio Doce e Vale do Suruaca no Município de Linhares, Estado do Espírito Santo, Brasil. Revista Brasileira de Zoociências, v.5, p.205-211, 2003.

SILVA, F.A.B.; HERNÁNDEZ, M.I.M.; IDE, S.; MOURA, R. de C. de. Comunidade de escarabeíneos (Coleoptera, Scarabaeidae) copro-necrófagos da região de Brejo Novo, Caruaru, Pernambuco, Brasil. Revista Brasileira de Entomologia, v.51, p.228-233, 2007. DOI: $10.1590 / \mathrm{S} 0085-56262007000200014$.

SILVA, P.G. da; AUDINO, L.D.; NOGUEIRA, J.M.; MORAES, L.P. de; VAZ-DE-MELLO, F.Z. Escarabeíneos (Coleoptera: Scarabaeidae: Scarabaeinae) de uma área de campo nativo no bioma Pampa, Rio Grande do Sul, Brasil. Biota Neotropica, v.12, p.1-9, 2012. DOI: 10.1590/S1676-06032012000300024.

SILVA, P.G. da; GARCIA, M.A. de R.; VIDAL, M.B. Besouros copro-necrófagos (Coleoptera: Scarabaeidae stricto sensu) coletados em ecótono natural de campo e mata em Bagé, RS. Ciência e Natura, v.30, p.71-91, 2008.

SILVA, R.J. da; DINIZ, S.; VAZ-DE-MELLO, F.Z. Heterogeneidade do habitat, riqueza e estrutura da assembléia de besouros rola-bostas (Scarabaeidae: Scarabaeinae) em áreas de Cerrado na Chapada dos Parecis, MT. Neotropical Entomology, v.39, p.934-940, 2010. DOI: 10.1590/S1519-566X2010000600014.

SILVA, R.J.; COLETTI, F.; COSTA, D.A.; VAZ-DE-MELLO, F.Z. Rola-bostas (Coleoptera: Scarabaeidae: Scarabaeinae) de florestas e pastagens no sudoeste da Amazônia brasileira: levantamento de espécies e guildas alimentares. Acta Amazonica, v.44, p.345-352, 2014. DOI: $10.1590 / 1809-4392201304472$.
VAZ-DE-MELLO, F.Z. Catálogo taxonômico da fauna do Brasil: Scarabaeidae Latreille, 1802. 2015. Available at: <http:// fauna.jbrj.gov.br/fauna/faunadobrasil/126713>. Accessed on: June 222016.

VAZ-DE-MELLO, F.Z. Estado atual de conhecimento dos Scarabaeidae s. str. (Coleoptera: Scarabaeoidea) do Brasil. In: MARTÍN-PIERA, F.; MORRONE, J.J.; MELIC, A. (Ed.). Hacia un Proyecto CYTED para el inventario y estimación de la diversidad entomológica en Iberoamérica: PrIBES-2000. Zaragoza: Sociedad Entomológica Aragones, 2000. p.183-195. (Monografías tercer milenio, 1).

VAZ-DE-MELLO, F.Z. Revision and phylogeny of the dung beetle genus Zonocopris Arrow 1932 (Coleoptera: Scarabaeidae: Scarabaeinae), a phoretic of land snails. Annales de la Société Entomologique de France, v.43, p.231-239, 2007. DOI: 10.1080/0 0379271.2007.10697516.

VAZ-DE-MELLO, F.Z. Synopsis of the new subtribe Scatimina (Coleoptera: Scarabaeidae: Scarabaeinae: Ateuchini), with descriptions of twelve new genera and review of Genieridium, new genus. Zootaxa, v.1955, p.1-75, 2008.

VAZ-DE-MELLO, F.Z.; EDMONDS, W.D.; OCAMPO, F.C.; SCHOOLMEESTERS, P. A multilingual key to the genera and subgenera of the subfamily Scarabaeinae of the New World (Coleoptera: Scarabaeidae). Zootaxa, v.2854, p.1-73, 2011.

VAZ-DE-MELLO, F.; LARSEN, T.; SILVA, F.; FAVILA, M.; SPECTOR, S.; GILL, B. Canthon corpulentus. 2013. DOI: 10.2305/IUCN.UK.2013-2.RLTS.T137131A520414.en.

VIEIRA, L.; LOUZADA, J.N.C.; SPECTOR, S. Effects of degradation and replacement of Southern Brazilian coastal sandy vegetation on the dung beetles (Coleoptera: Scarabaeidae). Biotropica, v.40, p.719-727, 2008. DOI: 10.1111/j.17447429.2008.00432.x.

WATERHOUSE, D.F. The biological control of dung. Scientific American, v.230, p.100-109, 1974. DOI: 10.1038/ scientificamerican0474-100.

$\overline{\text { Received on October 2, } 2015 \text { and accepted on August 4, } 2016}$

Pesq. agropec. bras., Brasília, v.52, n.6, p.401-418, jun. 2017

DOI: 10.1590/S0100-204X2017000600004 